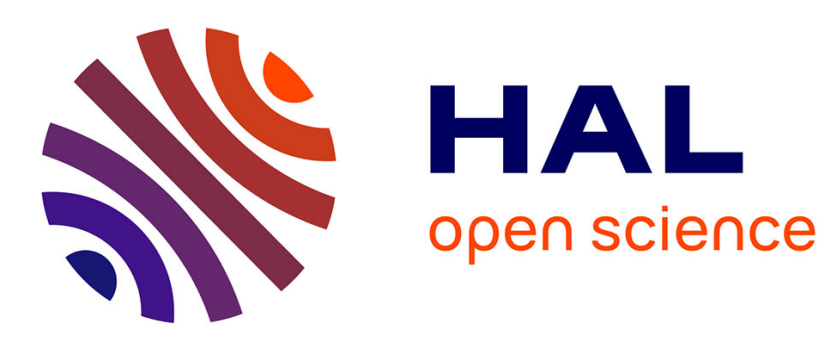

\title{
Xenobiotics removal by adsorption in the context of tertiary treatment: a mini review
}

\author{
A. Tahar, J.M. Choubert, Marina Coquery
}

\section{To cite this version:}

A. Tahar, J.M. Choubert, Marina Coquery. Xenobiotics removal by adsorption in the context of tertiary treatment: a mini review. Environmental Science and Pollution Research, 2013, 20, p. 5085 - p. 5095. 10.1007/s11356-013-1754-2 . hal-01072154

\section{HAL Id: hal-01072154 https://hal.science/hal-01072154}

Submitted on 7 Oct 2014

HAL is a multi-disciplinary open access archive for the deposit and dissemination of scientific research documents, whether they are published or not. The documents may come from teaching and research institutions in France or abroad, or from public or private research centers.
L'archive ouverte pluridisciplinaire HAL, est destinée au dépôt et à la diffusion de documents scientifiques de niveau recherche, publiés ou non, émanant des établissements d'enseignement et de recherche français ou étrangers, des laboratoires publics ou privés. 
XENOBIOTICS REMOVAL BY ADSORPTION IN THE CONTEXT OF TERTIARY TREATMENT- A MINI REVIEW

Alexandre TAHAR, Jean-Marc CHOUBERT*, Marina COQUERY

Irstea, UR MALY (Freshwater systems, ecology and pollution research unit)

5 rue de la DOUA, CS70077, 69626 VILLEURBANNE Cedex, France

\{alexandre.tahar@irstea.fr,jean-marc.choubert@irstea.fr, marina.coquery@irstea.fr\}

Tel: +33 (0)4 722087 87, Fax: +33 (0)4 78477875 .

* corresponding author

\section{KEYWORDS}

Langmuir parameters, pharmaceuticals, pesticides, batch studies, maximum adsorption capacity, wastewater treatment 


\begin{abstract}
Many xenobiotics, including several pharmaceuticals and pesticides, are poorly treated in domestic wastewater treatment plants. Adsorption processes, such as with activated carbons, could be a solution to curb their discharge into the aquatic environment. As adsorbent-like activated carbon is known to be expensive, identifying promising alternative adsorbent materials is a key challenge for efficient yet affordable xenobiotic removal from wastewaters. As part of the effort to address this challenge, we surveyed the literature on pharmaceutical and pesticide xenobiotics and built a database compiling data from 38 scientific publications covering 65 xenobiotics and 58 materials. Special focus was given to the relevance and comparability of the data, to the characteristics of the adsorbent materials used, and to the operating conditions of the batch-tests inventoried.
\end{abstract}

This paper gives an in-depth overview of the adsorption capacities of various adsorbents. The little data on alternative adsorbent materials, especially for the adsorption of pharmaceuticals, makes it difficult to single out any one activated carbon alternative capable of adsorbing pesticides and pharmaceuticals at the tertiary stage of treatment. There is a pressing need for further lab-scale experiments to investigate the tertiary treatment of discharged effluents. We conclude with recommendations on how future data should best be used and interpreted. 


\section{INTRODUCTION}

Research into the issue of environmental xenobiotics has recently surged. Many xenobiotics, like pharmaceutically-active compounds (PhACs) and pesticides, have been quantified in surface waters (Zuccato et al. 2000; Kolpin et al. 2002), ground waters (Ternes 2001; Heberer 2002) and drinking water (Jones et al. 2005; Togola and Budzinski 2008). To reduce xenobiotic release into the aquatic environment, EU regulations have promoted a phased reduction of xenobiotics discharge based on a regularly revised list of priority substances including pesticides and certain pharmaceuticals.

Conventional wastewater treatment plants (WWTPs) have been singled out as one of the main point-sources of xenobiotic transfer into the aquatic environment (Bendz et al. 2005; Carballa et al. 2004; Carballa et al. 2005; Lishman et al. 2006; Vieno et al. 2006; Palmer et al. 2008; Spongberg and Witter 2008). Indeed, treated effluents released by conventional WWTPs still contain significant concentrations of several xenobiotics, due to their poor biodegradation in secondary treatments and/or their high levels in raw influents. Pesticides and PhACs are of particular concern, since many of these substances are poorly biodegradable and highly hydrophilic. For instance, there are regular reports of effluent concentrations over $0.1 \mu \mathrm{g} \mathrm{L}{ }^{-1}$ for several pesticides (diuron, glyphosate, AMPA) and PhACs (e.g. sulfamethoxazol, roxithromycin, ibuprofen, carbamazepine, propranolol, acebutolol, atenolol, sotalol, paracetamol, ketoprofen, gemfibrozil, diclofenac (Ternes et al. 2004; Gabet-Giraud et al. 2010; Martin Ruel et al. 2010; Falås et al. 2012); and even reports of effluent concentrations over $1 \mu \mathrm{g} \mathrm{L}^{-1}$ for certain xenobiotics, including aminomethylphosphonic acid (AMPA), ibuprofen and gemfibrozil (Martin Ruel et al. 2010). 
Advanced processes, such as UV or ozone oxidation, nanofiltration (NF) and reverse osmosis (RO) have been shown to improve treatment for a majority of xenobiotics, with removal efficiencies of over $90 \%$ for many xenobiotics poorly eliminated in conventional WWTPs (Verlicchi et al. 2010; Martin Ruel et al. 2011). However, these processes are not "ecofriendly" (Wenzel et al. 2008; Høibye et al. 2008) and cannot be made sustainable until we address a number of issues such as the treatment of concentrate by $\mathrm{RO} / \mathrm{NF}$ processes or the formation of toxic metabolites during ozone oxidation (Verlicchi et al. 2010). Moreover, for economic reasons, these advanced processes are not yet viably adaptable to WWTPs below 50,000 population equivalents (PE), meaning alternative solutions need to be developed.

Activated carbons (AC) provide efficient retention of xenobiotics due to their microporous structure that offers very high specific areas of up to $2000 \mathrm{~m}^{2} \mathrm{~g}^{-1}$. Filtration on granular AC (GAC) enabled removal efficiencies of up to $90 \%$ for a majority of xenobiotics, including carbamazepine and diclofenac (e.g.(Westerhoff et al. 2005; Martin Ruel et al. 2011)). High removal efficiencies were also obtained by adding powder-activated carbon (PAC) into a membrane bioreactor, with removal efficiencies above $90 \%$ for atrazine, naproxen and estrone (Snyder et al. 2007). Nevertheless, the use of ACs at the tertiary treatment stage runs into several issues, notably their price and the environmental cost of the production/regeneration step (Crisafully et al. 2008; Verlicchi et al. 2010). Identifying alternative materials to AC is therefore a key issue for tertiary treatments to remove xenobiotics from WWTP effluent.

The last decade has seen a surge in papers on the adsorption capacities of chemical substances by various adsorbent materials (batch assay tests). Much of this literature is devoted to dyes (Crini 2006; Gupta and Suhas 2009), phenols (Ahmaruzzaman 2008) and heavy metals (Bailey et al. 1999; Babel and Kurniawan 2003). Besides ACs, reviews have also focused on 
wastes from industry or agriculture (Bhatnagar and Sillanpää 2010), chitosan and chitin derivatives (Bhatnagar and Sillanpää 2009), natural zeolites (Wang and Peng 2010), sawdust (Shukla et al. 2002), biosorbents such as dry activated sludge and yeast (Aksu 2005), polymeric materials (Pan et al. 2009) and cellulose-based materials (Wojnárovits et al. 2010), but unfortunately without reporting any data on pesticide and $\mathrm{PhAC}$ adsorption capacities. The relevant knowledge on PhACs and pesticides is spread across papers dealing with individual results from batch assays (i.e. one adsorbent in contact with one xenobiotic).

This paper set out to draw up a qualitative and quantitative overview compiling the available literature data describing the pesticide and PhAC adsorption potential of ACs, mineral adsorbents and other adsorbent materials. We set out with three aims: i) to identify the most promising AC alternatives capable of adsorbing hydrophilic xenobiotics; ii) to identify relationships between adsorption parameters based on material characteristics so as to predict adsorption potential, and iii) to recommend technical and research directions for refining and improving the data used. We thus built a database by compiling the results of experimental adsorption assays (Langmuir parameter values) found in the literature, including meta-data such as the physical-chemical characteristics of the adsorbents and the experimental conditions applied. Special attention was devoted to selecting the data and compiling reliable results relevant to adsorption potentiality.

\section{MATERIALS AND METHODS}

\subsection{Construction of the database}

We built a database compiling published Langmuir parameter data on various adsorbents tested with aqueous solutions at lab-scale in completely mixed-batch reactors (Homem and Santos 2011). The Langmuir model (equation 1) considers a maximum adsorption capacity 
('MAC', in $\mathrm{mg} \mathrm{g}^{-1}$ ) and an affinity constant ('b', in $\mathrm{L} / \mathrm{mg}$ ) to model the equilibrium values between the xenobiotic concentrations in an adsorbent material and the liquid phase:

$$
Q_{e}=\frac{M A C \cdot b \cdot C_{e}}{1+b \cdot C_{e}} \quad \text { Eq. (1) }
$$

The Langmuir parameters are always expressed in the same dimension, contrary to Freundlich parameters (Kf and $\mathrm{n}$ ) for which $\mathrm{Kf}$ unit depends on $\mathrm{n}$ value (Xu et al. 2009). Hence, the use of Langmuir parameters enabled us to compare MAC and b results between different studies.

We then imported physical-chemical characteristics of studied substances, such as $\log \mathrm{K}_{\mathrm{ow}}$, solubility, pKa, Henry's constant, and molecular weight. These values were extracted from http://www.syrres.com and http://toxnet.nlm.nih.gov (see Online Resource 1). We also collected physical characteristics such as specific area, pore volume and diameter, particle size, density, point of zero charge ' $\mathrm{pH}_{\mathrm{pzc}}$ ', plus chemical characteristics, and price. Crucially, we documented the conditions under which the Langmuir parameters were determined. These metadata describe the operating conditions of the batch experiments: initial concentration $\left(\mathrm{C}_{0}\right)$, water type (synthetic, surface, groundwater, release from a secondary WWTP), $\mathrm{pH}$, temperature, solid/liquid ratio, agitation speed, time to reach equilibrium conditions (see Online Resource 2 to see metadata on the experimental conditions applied).

\subsection{Data selection strategy}

We developed a strategy to exploit only selected results on Langmuir parameters values. This data selection strategy was implemented as follows:

- adsorbent materials produced from certain kinds of waste such as dried sludge (Aksu and Yener 1998) or plant material like sunflower stem waste (Sun and Xu 1997) or garlic peel (Hameed and Ahmad 2009) were excluded as they are not mechanically resistant in water and may consequently release undesirable xenobiotics into the aquatic environment; 
- we chose physical-chemical conditions within the usual range characteristic of domestic wastewater, i.e. $\mathrm{pH}$ in the range 5 to 9 and temperature in the range $5^{\circ} \mathrm{C}$ to $30^{\circ} \mathrm{C}$;

- we chose data on adsorption with the more frequent type and generated with spiked synthetic water for homogeneity reasons due to the lack of data on natural waters (such as rivers and groundwaters);

- we excluded results when time-to-equilibrium was longer than $24 \mathrm{~h}$, as this duration would not be relevant for a tertiary treatment application;

- experiments carried out in completely mixed reactors (batch) were ignored if carried out under conditions far removed from conventional secondary effluents treatment.

Consequently, the selected dataset thus selected originates from batch studies considering the adsorption of only one substance in synthetic water free of organic matter. We found no papers reporting adsorption performances for a cocktail of xenobiotics.

The database ultimately obtained contains data extracted from 38 research papers published between 1998 and 2010 (see Online Resource 3 for the full reference list). It gathers 108 individual data on MAC values (but only 43 corresponding b parameter values) concerning 65 xenobiotics (pesticides and pharmaceuticals) and 58 adsorbent materials.

\section{RESULTS}

\subsection{Description of the xenobiotics and the adsorbent materials in the database}

\subsubsection{Xenobiotics studied}

Among the data gathered in our database, pesticides were the most studied substances, with 63 data items followed by PhACs (45 data items), as shown in Figure 1. 
PHARMACEUTICALS $(\mathrm{PhAC})(\mathrm{n}=\mathbf{4 5})$

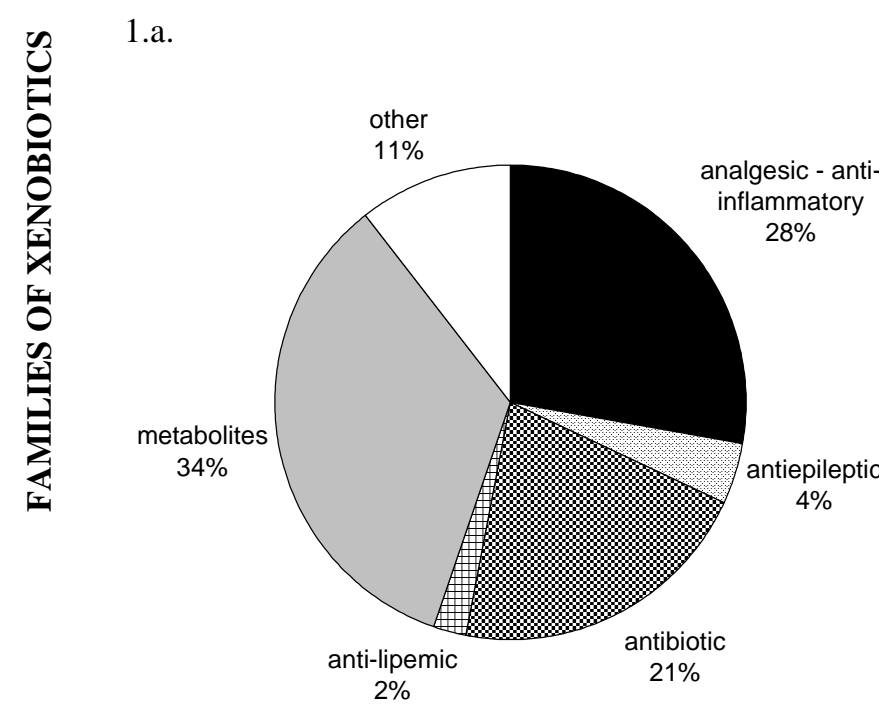

1.c.

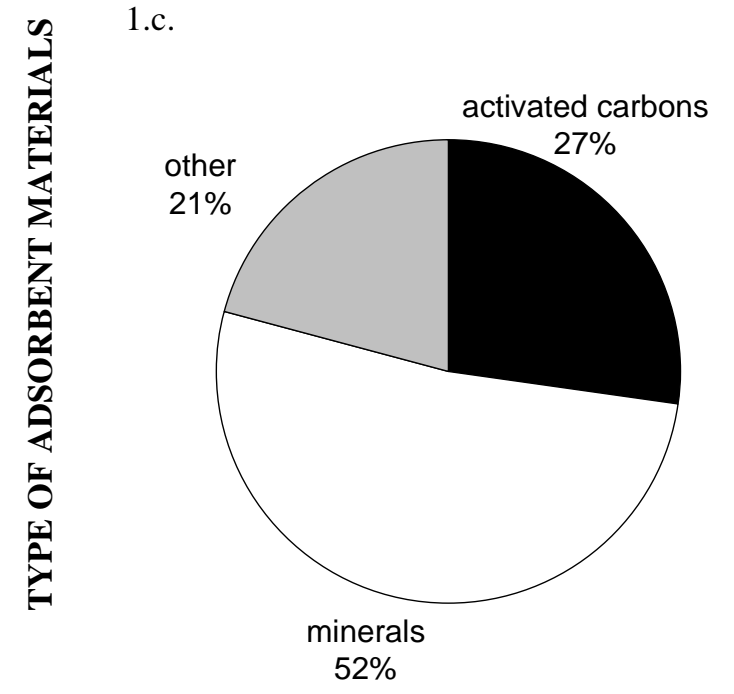

\section{PESTICIDES $(n=63)$}

1.b.

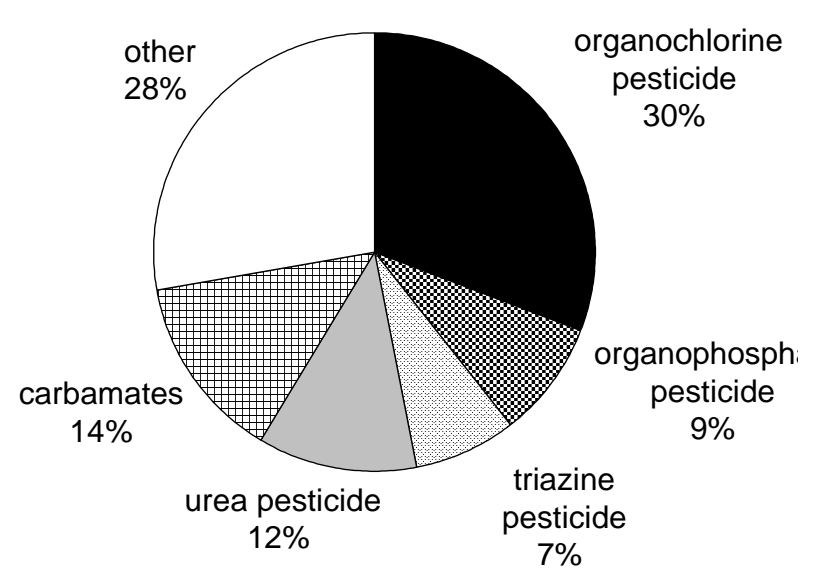

1.d.

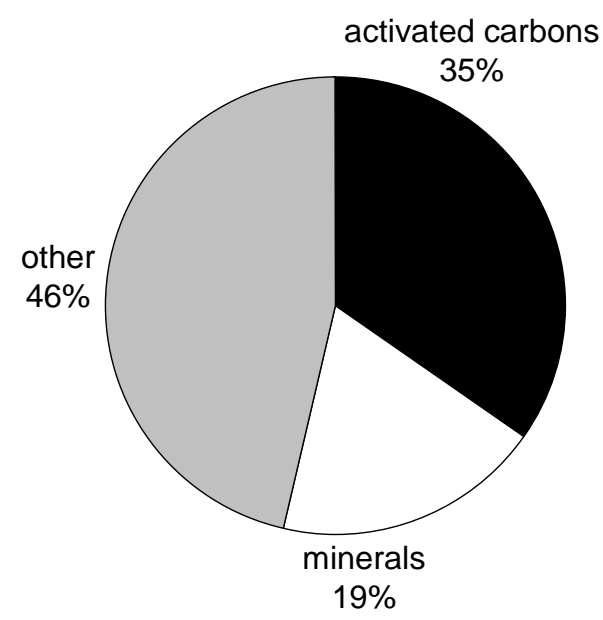

Fig 1 Distribution of MAC values in the database by xenobiotic family: a) pharmaceuticals, b) pesticides; and by type of adsorbent material - activated carbons (ACs), mineral absorbent and other absorbent materials- for c) pharmaceuticals and d) pesticides. (n: number of available MAC data).

The PhACs most represented were metabolites (salicylic acid and tetracycline hydrochloride; Figure 1.a), accounting for $34 \%$ of the $45 \mathrm{PhAC}$ data items, followed by analgesics/antiinflammatories (ibuprofen, ketoprofen, diclofenac) and antibiotics (amoxicillin, ciprofloxacin) which represented $28 \%$ and $21 \%$ of the pharmaceuticals, respectively. The 
PhACs most rarely studied for adsorption were anti-lipemic (clofibric acid) and antiepileptic (carbamazepine) substances that represented $2 \%$ and $4 \%$ of the $\mathrm{PhAC}$ data items, respectively.

The pesticides most represented were organochlorines (lindane, alachlor, acetochlor; Figure 1.b), accounting for $30 \%$ of the 65 pesticide data items, followed by carbamates and urea (diuron, isoproturon) which represented $14 \%$ and $12 \%$ of the pesticide data items, respectively. The pesticides least represented were organophosphates (diazinon, methylparathion) and triazines (atrazine, simazine) that represented $9 \%$ and $7 \%$ of the pesticide data items, respectively.

The literature only featured adsorption performances for a few of the xenobiotics usually measured in domestic treatment plants effluents (such as sulfamethoxazole, carbamazepine, diclofenac, isoproturon and diuron; (Ayranci and Hoda 2005; Polubesova et al. 2006; Sarkar et al. 2007; Bui and Choi 2009; Vergili and Barlas 2009)). Unfortunately, each data was measured on different adsorbent materials, making it difficult for us to use them.

\subsubsection{Adsorbent materials studied}

The available MAC data for ACs, mineral and other adsorbent materials are presented for PhACs (Figure 1.c) and pesticides (Figure 1.d). Complementary metadata on the description of adsorbent materials studied are detailed in Online Resource 4.

For PhACs, ACs represented $27 \%$ of the 45 data items. Alternative adsorbent materials were extensively studied ( $73 \%$ of the data: $52 \%$ on mineral materials and $21 \%$ on other adsorbent materials). For pesticides, ACs represented $35 \%$ of the 63 data items. Alternative adsorbents were also widely studied ( $65 \%$ of the data on pesticides: just $19 \%$ on mineral materials and 
$46 \%$ on other adsorbent materials). The ACs studied are commercial products that were manufactured from different sources such as cork (Mestre et al. 2009), coconut shell, wood (Quesada-Peñate et al. 2009), date stones (Hameed et al. 2009) or banana stalk (Salman and Hameed 2010). The mineral adsorbent materials studied were essentially composed of different classes of modified clays (e.g., (Polubesova et al. 2006; Chang et al. 2009a), one silica (Bui and Choi 2009) and one modified zeolite (Lemić et al. 2006). Clays were thermally and chemically modified to increase their porous structure and change their surface chemistry to improve adsorption affinity. Other adsorbent materials were generally organic and composed of chitosan derivatives (Adriano et al. 2005; Ding et al. 2009), polymeric materials (Otero et al. 2004; Vergili and Barlas 2009), some agricultural wastes such as rice bran (Adachi et al. 2001), or chestnut shells (Zuhra Memon et al. 2007).

\subsubsection{Substances and adsorbent materials suffering from a lack of data}

No Langmuir parameters were found for some substances poorly removed by conventional WWTPs, including a number of pesticides and metabolite (glyphosate, AMPA), pharmaceuticals such as the antibiotic roxithromycin and beta-blockers (atenolol, sotalol), and some personal care products such as galaxolide (Martin Ruel et al. 2010). Moreover, we found few data for some poorly-removed PhAC, including carbamazepine (two MAC data) and diclofenac (one MAC data). This relative lack of data could be due to the fact that these substances are still not regulated under environmental quality or drinking water standards.

Several adsorbent materials, even those that show adsorption potential (e.g. large specific area and pore volume), are still without Langmuir parameter data. For example, no Langmuir parameter values were found for apatite, despite the fact that it has been shown to possess a good adsorption/precipitation capacity for phosphorus (Molle et al. 2005). Chitin-based 
adsorbents such as chitosan and cyclodextrin have relatively good MAC values (> $\left.100 \mathrm{mg} \mathrm{g}^{-1}\right)$ for substances such as heavy metals (Babel and Kurniawan 2003) and dyes (Crini 2006), but have rarely if ever been studied for $\mathrm{PhAC}$ and pesticides adsorption. Peat is an organic material that has good adsorption capacities $\left(>100 \mathrm{mg} \mathrm{g}^{-1}\right)$ for metals such as chromium (Brown et al. 2000) but has not been studied for PhAC and pesticide adsorption. Finally, no data were found on pozzolan (natural volcanic rock with a highly-developed porous network such as zeolite) or coco fiber.

\subsection{Data on Langmuir parameters}

The MAC and $\mathrm{b}$ Langmuir parameter values available for PhACs and pesticides are presented in Table 1 and classified into 3 types of adsorbent (AC, mineral adsorbents, other adsorbents).

Table 1 Langmuir parameter values (MAC and b) included in the database

Pesticides: a organochlorine, ${ }^{\mathrm{b}}$ other, ${ }^{\mathrm{c}}$ triazin, ${ }^{\mathrm{d}}$ urea, ${ }^{\mathrm{e}}$ organophophate

Pharmaceuticals: ${ }^{\mathrm{f}}$ analgesic/anti-inflammatory, ${ }^{\mathrm{g}}{ }^{\circ}$ other, ${ }^{\mathrm{h}}$ metabolites, ${ }^{\mathrm{i}}$ antibiotics, ${ }^{\mathrm{j}}$ antiepileptic, ${ }^{\mathrm{k}}$ anti-lipemic.

\begin{tabular}{|c|c|c|}
\hline \multirow{3}{*}{ 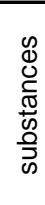 } & MCPA & $\begin{array}{l}\text { 2-methyl-4-chlorophenoxy } \\
\text { acetic acid }\end{array}$ \\
\hline & $2,4-D$ & 2,4-dichlorophenoxyacetic acid \\
\hline & MCPB & $\begin{array}{c}\text { 4-(4-chloro-o-tolyloxy)butyric } \\
\text { acid }\end{array}$ \\
\hline 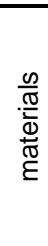 & $\begin{array}{c}\text { AC } \\
\text { F } 400 \\
S 2225 \\
\text { F } 300 \\
\text { PAC } \\
\text { GAC } \\
\text { BF }\end{array}$ & $\begin{array}{c}\text { activated carbon } \\
\text { filtrasorb } 400 \\
\text { Spectracarb } 2225 \\
\text { Filtrasorb } 300 \\
\text { powder activated carbon } \\
\text { granular activated carbon } \\
\text { Blast Furnace }\end{array}$ \\
\hline
\end{tabular}


Activated carbons (ACs)

\begin{tabular}{|c|c|c|c|c|}
\hline Material & Substance & $\begin{array}{l}\text { MAC } \\
(\mathrm{mg} / \mathrm{g})\end{array}$ & $\begin{array}{l}\mathbf{b} \\
(\mathrm{L} / \mathrm{mg})\end{array}$ & Reference \\
\hline F 400 & salicylic acid $^{\mathrm{h}}$ & 351 & 1.85E-05 & Otero et al. 2004 \\
\hline AC (norit row 0.8 SUPRA) & amoxicilin $^{i}$ & 190 & 0.03 & Putra et al. 2009 \\
\hline$\overline{A C}$ (cork powder) & ibuprofen $^{f}$ & 145 & 0.24 & \multirow{6}{*}{ Mestre et al. 2009} \\
\hline AC (cork, strong activation) & ibuprofen $^{f}$ & 378 & 0.10 & \\
\hline$P(A C$ from $P E T)$ & ibuprofen $^{f}$ & 267 & 0.49 & \\
\hline $\mathrm{AC}($ coal $)$ & ibuprofen $^{f}$ & 430 & 0.11 & \\
\hline AC (wood) & ibuprofen $^{f}$ & 292 & 0.17 & \\
\hline AC (wood, strong activation) & ibuprofen $^{f}$ & 149 & 0.06 & \\
\hline $\mathrm{AC}(\mathrm{wood})$ & levodopa ${ }^{g}$ & 317 & 0.02 & \multirow{3}{*}{ Quesada-penate et al. 2009} \\
\hline AC (coconut shell) & levodopa ${ }^{g}$ & 285 & 1.12 & \\
\hline AC (i-ian tree bark) & levodopa $^{\mathrm{g}}$ & 393 & 0.88 & \\
\hline \multirow{2}{*}{ F 400} & lindane a & 183 & - & \multirow{2}{*}{ Sotelo et al.2002 } \\
\hline & alachlor $^{\text {b }}$ & 151 & - & \\
\hline \multirow{4}{*}{ S 2225} & amtryn $^{c}$ & 355 & - & \multirow{4}{*}{ Ayranci and Hoda 2005} \\
\hline & aldicarb $^{\mathrm{b}}$ & 422 & - & \\
\hline & dinoseb $^{b}$ & 302 & - & \\
\hline & diuron $^{d}$ & 213 & - & \\
\hline \multirow{2}{*}{ S 2225} & bentazon ${ }^{\text {b }}$ & 151 & 0.57 & \multirow{2}{*}{ Ayranci and Hoda 2004} \\
\hline & propanil $^{\text {b }}$ & 114 & 0.32 & \\
\hline \multirow{2}{*}{ F 300} & carbofuran $^{\mathrm{b}}$ & 96.2 & 0.13 & \multirow{2}{*}{ Salman and Hameed 2010b } \\
\hline & $2,4-D^{a}$ & 182 & 0.10 & \\
\hline \multirow{3}{*}{ AC (WD-extra) } & $2,4-D^{a}$ & 70.0 & - & \multirow{3}{*}{ Ignatowicz 2009} \\
\hline & $\mathrm{MCPA}^{\mathrm{b}}$ & 2.0 & - & \\
\hline & MCPP ${ }^{b}$ & 0.5 & - & \\
\hline PAC 313W & lindane $^{a}$ & 412 & 1.00 & Kouras et al. 1998 \\
\hline \multirow{2}{*}{ darco G-60 } & bromoxynil $^{\text {b }}$ & 500 & - & \multirow{2}{*}{ Yang et al. 2004} \\
\hline & diuron $^{d}$ & 300 & - & \\
\hline PAC & carbofuran $^{\text {b }}$ & 190 & - & Fernandez-perez et al. 2005 \\
\hline PAC & isoproturon $^{d}$ & 104 & - & Sarkar et al. 2007 \\
\hline AC (date stones) & $2,4-D^{a}$ & 238 & - & Hameed et al. 2009 \\
\hline AC (banana stalk) & carbofuran $^{\text {b }}$ & 156 & 0.26 & Salman and Hameed 2010 \\
\hline AC (palm oil) & bentazon $^{\mathrm{b}}$ & 32.7 & - & Salman and Hameed 2010c \\
\hline \multirow{2}{*}{ AC (charcoal) } & $\mathrm{MCPB}^{\mathrm{b}}$ & 126 & - & \multirow{2}{*}{ Hu et al. 1998} \\
\hline & imazalil $^{\text {a }}$ & 208 & - & \\
\hline \multirow[t]{2}{*}{$\mathrm{AC}(\mathrm{ns})$} & $2,4-D^{a}$ & 303 & - & \multirow{2}{*}{ Gupta et al. 2006} \\
\hline & carbofuran $^{\mathrm{b}}$ & 266 & - & \\
\hline
\end{tabular}


Table 1 (continued)

Mineral materials

\begin{tabular}{|c|c|c|c|c|}
\hline Material & Substance & $\begin{array}{l}\text { MAC } \\
(\mathrm{mg} / \mathrm{g})\end{array}$ & $\begin{array}{l}\text { b } \\
(\mathrm{L} / \mathrm{mg})\end{array}$ & Reference \\
\hline \multirow{6}{*}{ modified clay } & tetracycline $^{\mathrm{h}}$ & 5.0 & - & \multirow{6}{*}{ Polubesova et al. 2006} \\
\hline & oxytetracycline $^{\mathrm{h}}$ & 5.0 & - & \\
\hline & chlortetracycline $^{\mathrm{h}}$ & 5.0 & - & \\
\hline & sulfamethoxazole $^{\mathrm{h}}$ & 5.0 & - & \\
\hline & sulfizoxazole $^{h}$ & 5.0 & - & \\
\hline & sulfamethizole $^{\mathrm{h}}$ & 5.0 & - & \\
\hline \multirow{5}{*}{ mesoporous silica } & carbamazepin $^{j}$ & 0.2 & 33.8 & \multirow{5}{*}{ Bui and Choi 2009} \\
\hline & clofibric acid $^{\mathrm{k}}$ & 0.1 & 22.2 & \\
\hline & diclofenac $^{f}$ & 0.3 & 2.61 & \\
\hline & ibuprofen $^{f}$ & 0.4 & 13.3 & \\
\hline & ketoprofen $^{f}$ & 0.3 & 14.7 & \\
\hline \multirow{2}{*}{ palygorskite } & tetracycline $^{\mathrm{h}}$ & 56.0 & 0.03 & \multirow{2}{*}{ Chang et al. 2009} \\
\hline & tetracycline $^{\mathrm{h}}$ & 99.0 & 0.03 & \\
\hline \multirow{2}{*}{ rectorite } & tetracycline $^{\mathrm{h}}$ & 140 & - & \multirow{2}{*}{ Chang et al. 2009b } \\
\hline & tetracycline $^{\mathrm{h}}$ & 107 & - & \\
\hline SW y-2 Na-Montmorillonite & tetracycline $^{\mathrm{h}}$ & 355 & - & \multirow{3}{*}{ Chang et al. 2009c } \\
\hline SA z-1 Ca-Montmorilonite & tetracycline $^{\mathrm{h}}$ & 460 & - & \\
\hline rectorite & tetracycline $^{\mathrm{h}}$ & 140 & - & \\
\hline bentonite & amoxicilin $^{i}$ & 47.4 & 0.01 & Putra et al. 2009 \\
\hline goethite (syn-FeOOH) & ciprofloxacin $^{i}$ & 49.6 & 0.24 & \multirow{2}{*}{ Zhang and Huang 2007} \\
\hline goethite (ald-Fe-OOH) & ciprofloxacin $^{\mathrm{i}}$ & 33.1 & 0.01 & \\
\hline goethite & salicylic acid $^{\mathrm{h}}$ & 31.7 & - & \multirow{4}{*}{ Xu et al. 2007} \\
\hline kaolinite & salicylic acid $^{\mathrm{h}}$ & 5.2 & - & \\
\hline rhodic ferrasol & salicylic acid $^{\mathrm{h}}$ & 17.9 & - & \\
\hline haplic acrisol & salicylic acid $^{\mathrm{h}}$ & 11.8 & - & \\
\hline bituminous shale & $2,4-D^{a}$ & 1.9 & - & Ayar et al. 2008 \\
\hline \multirow{3}{*}{ modified natural zeolite } & atrazine $^{c}$ & 0.4 & - & \multirow{3}{*}{ Lemic et al. 2006} \\
\hline & lindane $^{a}$ & 1.0 & - & \\
\hline & diazinon $^{\mathrm{e}}$ & 1.3 & - & \\
\hline
\end{tabular}


Table 1 (continued)

Other materials

\begin{tabular}{|c|c|c|c|c|}
\hline Material & Substance & $\begin{array}{l}\text { MAC } \\
(\mathrm{mg} / \mathrm{g})\end{array}$ & $\begin{array}{l}\text { b } \\
(\mathrm{L} / \mathrm{mg})\end{array}$ & Reference \\
\hline \multirow{2}{*}{$\begin{array}{l}\text { chisosan alginate } \\
\text { (microgranules shells ) }\end{array}$} & salicylic acid $^{\mathrm{h}}$ & 3.0 & - & \multirow{2}{*}{ Ding et al. 2009} \\
\hline & $2,4-D^{a}$ & 4.3 & - & \\
\hline chitosan beads & amoxicilin $^{\mathrm{i}}$ & 8.7 & - & Adriano et al. 2005 \\
\hline \multirow{3}{*}{$\begin{array}{l}\text { polymeric resin (lewatit VP OC } \\
1163 \text { ) }\end{array}$} & carbamazepine $^{j}$ & 3.9 & - & \multirow{3}{*}{ Vergeli and Barlas 2009} \\
\hline & propyphenazone $^{f}$ & 3.9 & - & \\
\hline & sulfamethoxazole ${ }^{i}$ & 3.9 & - & \\
\hline \multirow{2}{*}{ sephabeads SP207 (polymeric) } & salicylic acid $^{\mathrm{h}}$ & 81.6 & 2.03E-07 & \multirow[b]{2}{*}{ Otero et al. 2004} \\
\hline & salicylic acid $^{\mathrm{h}}$ & 45.2 & $1.27 \mathrm{E}-08$ & \\
\hline \multirow{22}{*}{ rice bran } & $\operatorname{captan}^{2}$ & 4.9 & - & \multirow{22}{*}{ Adachi et al. 2001} \\
\hline & chloromethoxyphen $^{a}$ & 4.4 & - & \\
\hline & chloronitrophen $^{\mathrm{b}}$ & 4.7 & - & \\
\hline & cypermethrin $^{\text {b }}$ & 0.2 & - & \\
\hline & dichlofluanid ${ }^{\mathrm{b}}$ & 4.9 & - & \\
\hline & fenoxycarb ${ }^{b}$ & 2.6 & - & \\
\hline & phthalide $^{\mathrm{a}}$ & 2.7 & - & \\
\hline & $\mathrm{A}-\mathrm{HCH}{ }^{\mathrm{b}}$ & 4.2 & - & \\
\hline & hexachlorobenzen $^{a}$ & 4.3 & - & \\
\hline & hexythiazox ${ }^{\mathrm{b}}$ & 3.5 & - & \\
\hline & dicofol $^{a}$ & 4.4 & - & \\
\hline & methopren ${ }^{\mathrm{b}}$ & 3.9 & - & \\
\hline & carbendazim b & 1.1 & - & \\
\hline & oxadiazon $^{\text {b }}$ & 3.9 & - & \\
\hline & phoxim $^{a}$ & 3.3 & - & \\
\hline & propyzamide $^{\mathrm{b}}$ & 2.0 & - & \\
\hline & pyrazoxyfen ${ }^{\mathrm{b}}$ & 3.9 & - & \\
\hline & tetradifon $^{a}$ & 4.6 & - & \\
\hline & cholorobenzilate $^{b}$ & 3.9 & - & \\
\hline & triuram $^{\mathrm{b}}$ & 2.7 & - & \\
\hline & clofentezin ${ }^{\mathrm{b}}$ & 4.8 & - & \\
\hline & chorothalonil $^{\mathrm{a}}$ & 4.2 & - & \\
\hline water melon peel & methyl parathion ${ }^{\mathrm{e}}$ & 6.4 & - & Memon et al. 2008 \\
\hline \multirow{2}{*}{ chestnut shell } & carbofuran $^{\mathrm{b}}$ & 2.4 & - & \multirow{2}{*}{ Memon et al. 2007} \\
\hline & methyl parathion ${ }^{\mathrm{e}}$ & 5.9 & - & \\
\hline rice husk & triazofos $^{\mathrm{c}}$ & 0.9 & 0.08 & \multirow{2}{*}{ Akhtar et al. 2009} \\
\hline rice bran & triazofos $^{c}$ & 1.0 & 0.15 & \\
\hline \multirow{4}{*}{ XAD-7 (polymeric) } & amitrole $^{b}$ & 5.4 & 0.01 & \multirow{8}{*}{ Kyriakopoulos et al. 2005} \\
\hline & prometryn $^{c}$ & 3.9 & 0.03 & \\
\hline & alachlor $^{\mathrm{b}}$ & 7.4 & 0.10 & \\
\hline & trifluralin ${ }^{\mathrm{b}}$ & 10.2 & 0.09 & \\
\hline \multirow{4}{*}{ XAD-4 (polymeric) } & amitrole $^{\mathrm{b}}$ & 4.7 & 0.002 & \\
\hline & prometryn $^{c}$ & 11.3 & 0.02 & \\
\hline & alachlor ${ }^{b}$ & 7.6 & 0.03 & \\
\hline & trifluralin ${ }^{b}$ & 11.2 & 0.26 & \\
\hline \multirow{2}{*}{ carboneous (i-ustrial waste) } & $2,4-D^{a}$ & 212 & 0.02 & \multirow{8}{*}{ Gupta et al. 2006} \\
\hline & carbofuran $^{\mathrm{b}}$ & 208 & 0.02 & \\
\hline \multirow{2}{*}{ BF sludge } & $2,4-D^{a}$ & 30.0 & - & \\
\hline & carbofuran $^{\mathrm{b}}$ & 23.0 & - & \\
\hline \multirow{2}{*}{ BF dust } & $2,4-D^{a}$ & 21.0 & - & \\
\hline & carbofuran $^{\mathrm{b}}$ & 13.0 & - & \\
\hline \multirow{2}{*}{ BF slag } & $2,4-D^{a}$ & 0.0 & - & \\
\hline & carbofuran $^{b}$ & 0.0 & - & \\
\hline
\end{tabular}




\subsubsection{MAC values}

AC materials showed generally high MAC values for the adsorption of PhACs and pesticides. MAC values reported for Filtrasorb® 400 AC reach 137, 161 and $351 \mathrm{mg} \mathrm{g}^{-1}$ for adsorption of 2,4-dichlorophenoxyacetic acid (2,4-D) (Kim et al. 2008), lindane (Sotelo et al. 2002) and salicylic acid (Otero et al. 2004), respectively. ACs synthesized from non-conventional materials also show high MAC values, at $238 \mathrm{mg} \mathrm{g}^{-1}$ for the adsorption of 2,4-D in contact with AC processed from date stones (Hameed et al. 2009) or $156 \mathrm{mg} \mathrm{g}^{-1}$ for the adsorption of carbofuran in contact with AC processed from banana stalks (Salman and Hameed 2010).

Mineral and other alternative materials generally post lower MAC values than ACs. For mineral materials, reported values are in the range 0.1 to $50 \mathrm{mg} \mathrm{g}^{-1}$ for $\mathrm{PhACs}$ and 0.1 to $17 \mathrm{mg} \mathrm{g}^{-1}$ for pesticides. Values ranged from 0.1 to $0.4 \mathrm{mg} \mathrm{g}^{-1}$ for several pharmaceuticals (carbamazepine, clofibric acid, diclofenac, ibuprofen, ketoprofen) in contact with a mesoporous silica (Bui and Choi 2009) and from 0.4 to $1.3 \mathrm{mg} \mathrm{g}^{-1}$ for pesticides (atrazine, lindane, diazinon) in contact with zeolite (Lemić et al. 2006). Values in the range 5 to $50 \mathrm{mg} \mathrm{g}^{-1}$ were obtained for 6 antibiotics (tetracycline and derivates, and sulfamethoxazol and derivates) in contact with modified clay (Polubesova et al. 2006) and for salicylic acid and ciprofloxacin in contact with mineral materials such as goethite, kaolinite or bentonite (Xu et al. 2007; Zhang and Huang 2007). Only thermally or chemically-treated modified clays (montmorillonites, rectorites and palygorskites) had high MAC values of 460, 140 and $99 \mathrm{mg} \mathrm{g}^{-1}$, respectively, for the adsorption of tetracycline antibiotic (Chang et al. 2009a; Chang et al. 2009b). 
For alternative materials, MAC values ranged from 1 to $30 \mathrm{mg} \mathrm{g}^{-1}$, i.e. similar to the range measured for mineral adsorbents. Only two adsorbents showed higher MAC values: sephabeads (polymeric material) at 45 and $82 \mathrm{mg} \mathrm{g}^{-1}$ for salicylic acid (Otero et al. 2004), and carbonaceous industrial waste at MAC values ranging from 208 and $212 \mathrm{mg} \mathrm{g}^{-1}$ for the adsorption of two pesticides (carbofuran and 2,4-D, respectively) (Gupta et al. 2006).

\subsection{2. b values}

Published papers gave b Langmuir parameter values for less than a half of the $108 \mathrm{MAC}$ data items collected (43 b data). Except for specially modified adsorbents, b values are generally 10-fold higher for ACs than for mineral/other adsorbent materials (around $0.1 \mathrm{~L} \mathrm{mg}^{-1}$ for AC versus $0.01 \mathrm{~L} \mathrm{mg}^{-1}$ for alternative adsorbent materials). Specific treatment and/or synthesis can yield very high $b$ values for alternative adsorbents (up to $30 \mathrm{~L} \mathrm{mg}^{-1}$ ) showing a great affinity between adsorbent material and target xenobiotic (Bui and Choi 2009).

\section{DISCUSSION}

\subsection{Comparing alternative adsorbent materials to activated carbons}

Despite high differences between reported experiment results, our database demonstrated that ACs boast very high adsorption capacities for hydrophilic xenobiotics and clearly outperform other mineral or alternative material adsorbents. Data on alternative adsorbent materials to $\mathrm{ACs}$ is rare and largely inappropriate for comparing potential xenobiotic adsorbability, as there is little data available on the same xenobiotic treated with different adsorbent materials. MAC values for both ACs and alternative adsorbents were only available for 5 pesticides (2,4-D, carbofuran, alachlor, atrazine, lindane) and 4 PhACs (amoxicilin, ibuprofen, ketoprofen, salicylic acid). ACs showed 10 to 100 -fold higher MAC values than alternative adsorbent materials: for 2,4-D adsorption, AC and chitosan alginate adsorbent materials 
reached MAC values of 137 and $4.3 \mathrm{mg} \mathrm{g}^{-1}$, respectively (Kim et al. 2008; Ding et al. 2009), and for ibuprofen adsorption, AC from coal and mesoporous silica reached MAC values of 430 and $0.4 \mathrm{mg} \mathrm{g}^{-1}$, respectively (Mestre et al. 2009; Bui and Choi 2009). The only b parameter values available for both ACs and alternative adsorbent materials concerned a pharmaceutical (ibuprofen). In this case, $b$ value was very high $\left(13.3 \mathrm{~L} \mathrm{mg}^{-1}\right)$ for the alternative material as it is chemically modified, but this value remains unusual for such adsorbents.

To explore the differences between reported experiment results and get a more thorough basis for cross-comparing adsorption capacities between alternative adsorbent materials, different materials need to be tested using a common batch-test procedure. Indeed, from one study to another, the data were collected under various experimental conditions working with different initial xenobiotic concentrations (from dozens to several hundred $\mathrm{mg} \mathrm{L}^{-1}$ ) and different solid/liquid ratios $\left(0.01\right.$ to $\left.100 \mathrm{~g} \mathrm{~L}^{-1}\right)$, as shown in Online Resource 2. Besides the fact that these differences limit the scope for comparison between alternative materials, those values are very far from the concentration levels measured in WWTPs effluents (few $n g \mathrm{~L}^{-1}$ to $\left.\mu \mathrm{g} \mathrm{L}^{-1}\right)$. These differences may support competition phenomenon or pore blocking, and may alter the data quality and utilization of adsorption results published in literature (Limousin et al. 2007; De Ridder et al. 2011).

\subsection{Relationships between Langmuir parameters and adsorbent and xenobiotic characteristics}

The aim here was to determine potential relationships between Langmuir parameters and the characteristics of substances and adsorbent materials in order to predict MAC and b parameters based on material characteristics. We ran principal component analysis (PCA) on 
the dataset composed of the 22 cases where the following variables were fully documented in the database: MAC and $b$ Langmuir parameters, specific area and pore volume of the adsorbent material (other characteristics were too rarely mentioned), $\log \mathrm{K}_{\mathrm{ow}}$, molecular weight and solubility of the xenobiotics (Figure 2). The subset of data was composed of 11 data items from ACs, 6 from mineral materials and 5 from other alternative materials.

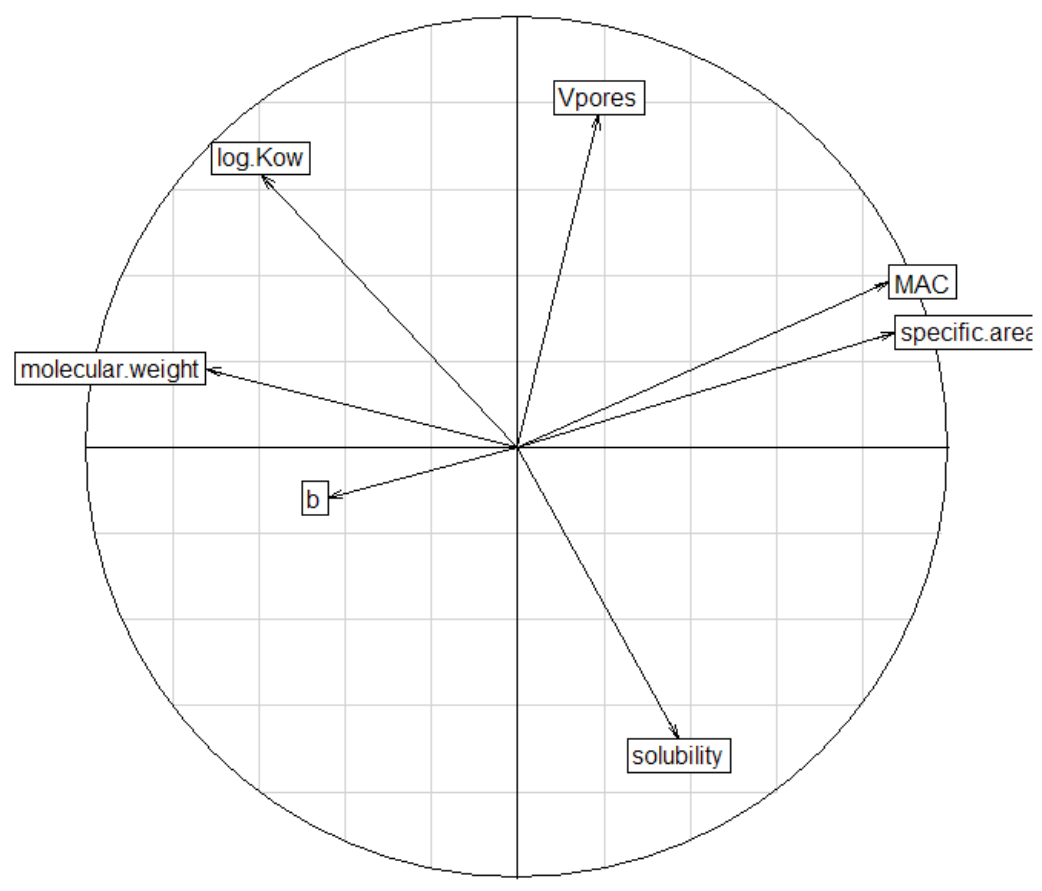

Fig 2 Correlation circle of PCA analysis (axes 1-2) with Langmuir parameters (MAC and b) and possible explanatory variables for studied adsorbent materials (specific surface area and pore volume) and for target xenobiotics (molecular weight, solubility, $\log \mathrm{K}_{\mathrm{ow}}$ ). Data set: $\mathrm{n}=22$.

As shown in Figure 2, we found a relationship between MAC and specific area, as the projections of vectors onto the plane represented by axes 1-2 were collinear, and the variance was well explained. In contrast, MAC was unrelated to pore volume of adsorbent materials and unrelated to substance characteristics such as $\log \mathrm{K}_{\mathrm{ow}}$ and solubility. These results warrant care, as they only concern a limited dataset $(n=22)$. We therefore checked the robustness of the approach by plotting MAC versus specific area with a larger dataset extracted from the database $(\mathrm{n}=106)$ (data not shown). We found no evidence of the 
relationship suggested earlier (via PCA analysis) between MAC and specific surface area of the adsorbent materials. Indeed, some materials with a high specific area $\left(>1000 \mathrm{~m}^{2} \mathrm{~g}^{-1}\right)$ showed low MAC values, and vice-versa. Thus, the MAC parameter could not be predicted based solely on specific area of the materials. The observed differences may be explained by other parameters rarely mentioned in research papers, such as pore volume, pore diameter or chemical characteristics. To go further in the interpretation and/or prediction of adsorption results, researchers should also consider xenobiotic hydrophobicity, polarizability, aromaticity and presence of H-bond donor/acceptor moieties, as with the quantitative structure-activity relationship (QSAR) model developed for one AC (de Ridder et al. 2010). The b Langmuir parameter representing xenobiotic affinity to material surface was not correlated to any of the considered variables. This could be due to the fact that this PCA was unable to integrate information on the material surface chemistry or chemical moieties of the xenobiotics.

\subsection{Influence of $b$ Langmuir parameter on adsorption}

b values were unfortunately not systematically published with MAC values (108 MAC items but only $43 \mathrm{~b}$ items). This is nevertheless a key issue when studying xenobiotics present at very low concentrations. If we consider for instance the adsorption of pesticide 2,4-D, AC F300 gave MAC and b values of $182 \mathrm{mg} \mathrm{g}^{-1}$ and $0.1 \mathrm{~L} \mathrm{mg}^{-1}$, respectively; while chitosan alginate gave values of $4.3 \mathrm{mg} \mathrm{g}^{-1}$ and an undetermined b value (Ding et al. 2009). Based on MAC values only, AC emerges as the best material for the adsorption of 2,4-D, but for a low equilibrium concentration in liquid of $\mathrm{C}_{\mathrm{e}}=0.001 \mathrm{mg} \mathrm{L}^{-1}$, chitosan alginate showed an higher equilibrium concentration in solid $\left(Q_{e}=0.042 \mathrm{mg} \mathrm{g}^{-1}\right)$ than $\mathrm{AC}\left(\mathrm{Q}_{\mathrm{e}}=0.018 \mathrm{mg} \mathrm{g}^{-1}\right)$. Thus, considering the strong influence of the Langmuir $b$ parameter on $Q_{e}$ at low $C_{e}$ levels, we recommend systematically evaluating this parameter for use in WWTP applications. 


\section{CONCLUSIONS}

Using an original database approach, we compiled literature values of Langmuir parameters (MAC and b) for various adsorbents in contact with synthetic water spiked with individual xenobiotics (pesticides and pharmaceuticals). A total of $108 \mathrm{MAC}$ and $43 \mathrm{~b}$ Langmuir data items were sorted for three types of adsorbents (i.e. ACs, mineral adsorbents, alternative adsorbent materials). We found 12 and 22 MAC values for the adsorption of PhACs and pesticides on ACs but only 33 and 41 MAC values for the adsorption of PhACs and pesticides on all alternative adsorbent materials. Using our database, we demonstrated that activated carbons offer clearly superior adsorption capacities for hydrophilic xenobiotics compared to other mineral or alternative materials that perform far less well. But the lower price of alternative materials compared to activated carbons could be a driving force for their use in wastewater treatment. Indeed, activated carbons cost about $1000 €$ per ton, while alternative materials such as clays and zeolites cost about $30 €$ per ton (Rakić et al. 2012) The broad range of reported values and low number of data available make it difficult to reliably crosscompare alternative materials. To progress on the comparison of adsorption capacities between alternative adsorbent materials, we need a higher number of data, covering the full panel of potential adsorbent materials. Data produced using a common batch-test procedure would greatly improve the comparability of adsorption performances. We recommend that authors detail the physical-chemical characteristics (e.g. surface chemistry) of the adsorbent material and determine Langmuir b parameter together with MAC value, as b parameter greatly influences the calculation of the adsorbed value Qe.

The work underlines that on the basis of the available literature data, it remains difficult to select an alternative material to AC capable of adsorbing pesticides and $\mathrm{PhACs}$ at a tertiary treatment stage. Further lab-scale experiments should be carried out using a common 
experimental protocol for different adsorbents. Studying adsorption under the presence of a cocktail of several xenobiotics (not studied individually) would give useful information on competition and interactions.

\section{ACKNOWLEDGMENTS}

The authors thank the French National Agency for Water and Aquatic Ecosystems (ONEMA) for providing funding.

\section{REFERENCES}

Adachi A, Takagi S, Okano T (2001) Studies on removal efficiency of rice bran for pesticides. Journal of Health Science 47 (2):94-98

Adriano WS, Veredas V, Santana CC, Gonçalves LRB (2005) Adsorption of amoxicillin on chitosan beads: Kinetics, equilibrium and validation of finite bath models. Biochemical Engineering Journal 27 (2):132-137

Ahmaruzzaman M (2008) Adsorption of phenolic compounds on low-cost adsorbents: A review. Advances in Colloid and Interface Science 143 (1-2):48-67

Aksu Z (2005) Application of biosorption for the removal of organic pollutants: A review. Process Biochemistry 40 (3-4):997-1026

Aksu Z, Yener J (1998) Investigation of the biosorption of phenol and monochlorinated phenols on the dried activated sludge. Process Biochemistry 33 (6):649-655

Ayranci E, Hoda N (2005) Adsorption kinetics and isotherms of pesticides onto activated carbon-cloth. Chemosphere 60 (11):1600-1607

Babel S, Kurniawan TA (2003) Low-cost adsorbents for heavy metals uptake from contaminated water: A review. Journal of Hazardous Materials 97 (1-3):219-243

Bailey SE, Olin TJ, Bricka RM, Adrian DD (1999) A review of potentially low-cost sorbents for heavy metals. Water Research 33 (11):2469-2479

Bendz D, Paxéus NA, Ginn TR, Loge FJ (2005) Occurrence and fate of pharmaceutically active compounds in the environment, a case study: Höje River in Sweden. Journal of Hazardous Materials 122 (3):195-204

Bhatnagar A, Sillanpää M (2009) Applications of chitin- and chitosan-derivatives for the detoxification of water and wastewater - A short review. Advances in Colloid and Interface Science 152 (1-2):26-38

Bhatnagar A, Sillanpää M (2010) Utilization of agro-industrial and municipal waste materials as potential adsorbents for water treatment-A review. Chemical Engineering Journal 157 (2-3):277-296

Brown PA, Gill SA, Allen SJ (2000) Metal removal from wastewater using peat. Water Research 34 (16):3907-3916

Bui TX, Choi H (2009) Adsorptive removal of selected pharmaceuticals by mesoporous silica SBA-15. Journal of Hazardous Materials 168 (2-3):602-608 
Carballa M, Omil F, Lema JM, Llompart M, García-Jares C, Rodríguez I, Gómez M, Ternes $\mathrm{T}$ (2004) Behavior of pharmaceuticals, cosmetics and hormones in a sewage treatment plant. Water Research 38 (12):2918-2926

Carballa M, Omil F, Lema JM, Llompart M, García C, Rodriguez I, Gómez M, Ternes T (2005) Behaviour of pharmaceuticals and personal care products in a sewage treatment plant of northwest Spain. Water Science and Technology 52 (8):29-35

Chang PH, Li Z, Jiang WT, Jean JS (2009a) Adsorption and intercalation of tetracycline by swelling clay minerals. Applied Clay Science 46 (1):27-36

Chang PH, Li Z, Yu TL, Munkhbayer S, Kuo TH, Hung YC, Jean JS, Lin KH (2009b) Sorptive removal of tetracycline from water by palygorskite. Journal of Hazardous Materials 165 (1-3):148-155

Crini G (2006) Non-conventional low-cost adsorbents for dye removal: A review. Bioresource Technology 97 (9):1061-1085

Crisafully R, Milhome MAL, Cavalcante RM, Silveira ER, De Keukeleire D, Nascimento RF (2008) Removal of some polycyclic aromatic hydrocarbons from petrochemical wastewater using low-cost adsorbents of natural origin. Bioresource Technology 99 (10):4515-4519

De Ridder DJ, Verliefde ARD, Heijman SGJ, Verberk JQJC, Rietveld LC, Van Der Aa LTJ, Amy GL, Van Dijk JC (2011) Influence of natural organic matter on equilibrium adsorption of neutral and charged pharmaceuticals onto activated carbon. Water Science and Technology 63 (3):416-423

de Ridder DJ, Villacorte L, Verliefde ARD, Verberk JQJC, Heijman SGJ, Amy GL, van Dijk JC (2010) Modeling equilibrium adsorption of organic micropollutants onto activated carbon. Water Research 44 (10):3077-3086

Ding Y, Zhao Y, Tao X, Zheng YZ, Chen JF (2009) Assembled alginate/chitosan microshells for removal of organic pollutants. Polymer 50 (13):2841-2846

Falås P, Andersen HR, Ledin A, La Cour Jansen J (2012) Occurrence and reduction of pharmaceuticals in thewater phase at Swedish wastewater treatment plants. Water Science and Technology 66 (4):783-791

Gabet-Giraud V, Miège C, Choubert JM, Ruel SM, Coquery M (2010) Occurrence and removal of estrogens and beta blockers by various processes in wastewater treatment plants. Science of the Total Environment 408 (19):4257-4269

Gupta VK, Ali I, Suhas, Saini VK (2006) Adsorption of 2,4-D and carbofuran pesticides using fertilizer and steel industry wastes. Journal of Colloid and Interface Science 299 (2):556-563

Gupta VK, Suhas (2009) Application of low-cost adsorbents for dye removal - A review. Journal of Environmental Management 90 (8):2313-2342

Hameed BH, Ahmad AA (2009) Batch adsorption of methylene blue from aqueous solution by garlic peel, an agricultural waste biomass. Journal of Hazardous Materials 164 (23):870-875

Hameed BH, Salman JM, Ahmad AL (2009) Adsorption isotherm and kinetic modeling of 2,4-D pesticide on activated carbon derived from date stones. Journal of Hazardous Materials 163 (1):121-126

Heberer T (2002) Tracking persistent pharmaceutical residues from municipal sewage to drinking water. Journal of Hydrology 266 (3-4):175-189

Høibye L, Clauson-Kaas J, Wenzel H, Larsen HF, Jacobsen BN, Dalgaard O (2008) Sustainability assessment of advanced wastewater treatment technologies. Water Science and Technology 58 (5):963-968

Homem V, Santos L (2011) Degradation and removal methods of antibiotics from aqueous matrices - A review. Journal of Environmental Management 92 (10):2304-2347 
Jones OA, Lester JN, Voulvoulis N (2005) Pharmaceuticals: A threat to drinking water? Trends in Biotechnology 23 (4):163-167

Kim TY, Park SS, Kim SJ, Cho SY (2008) Separation characteristics of some phenoxy herbicides from aqueous solution. Adsorption 14 (4-5):611-619

Kolpin DW, Furlong ET, Meyer MT, Thurman EM, Zaugg SD, Barber LB, Buxton HT (2002) Pharmaceuticals, hormones, and other organic wastewater contaminants in U.S. streams, 1999-2000: A national reconnaissance. Environmental Science and Technology 36 (6):1202-1211

Lemić J, Kovačević D, Tomašević-Čanović M, Stanić T, Pfend R (2006) Removal of atrazine, lindane and diazinone from water by organo-zeolites. Water Research 40 (5):10791085

Limousin G, Gaudet JP, Charlet L, Szenknect S, Barthès V, Krimissa M (2007) Sorption isotherms: A review on physical bases, modeling and measurement. Applied Geochemistry 22 (2):249-275

Lishman L, Smyth SA, Sarafin K, Kleywegt S, Toito J, Peart T, Lee B, Servos M, Beland M, Seto P (2006) Occurrence and reductions of pharmaceuticals and personal care products and estrogens by municipal wastewater treatment plants in Ontario, Canada. Science of the Total Environment 367 (2-3):544-558

Martin Ruel S, Choubert JM, Esperanza M, Miège C, Navalón Madrigal P, Budzinski H, Le Ménach K, Lazarova V, Coquery M (2011) On-site evaluation of the removal of 100 micro-pollutants through advanced wastewater treatment processes for reuse applications. Water Science and Technology 63 (11):2486-2497

Martin Ruel S, Esperanza M, Choubert JM, Valor I, Budzinski H, Coquery M (2010) On-site evaluation of the efficiency of conventional and advanced secondary processes for the removal of 60 organic micropollutants. Water Science and Technology 62 (12):29702978

Mestre AS, Pires J, Nogueira JMF, Parra JB, Carvalho AP, Ania CO (2009) Waste-derived activated carbons for removal of ibuprofen from solution: Role of surface chemistry and pore structure. Bioresource Technology 100 (5):1720-1726

Molle P, Liénard A, Grasmick A, Iwema A, Kabbabi A (2005) Apatite as an interesting seed to remove phosphorus from wastewater in constructed wetlands. Water Science and Technology 51:193-203

Otero M, Grande CA, Rodrigues AE (2004) Adsorption of salicylic acid onto polymeric adsorbents and activated charcoal. Reactive and Functional Polymers 60 (1-3):203213

Palmer PM, Wilson LR, O'Keefe P, Sheridan R, King T, Chen CY (2008) Sources of pharmaceutical pollution in the New York City Watershed. Science of the Total Environment 394 (1):90-102

Pan B, Zhang W, Lv L, Zhang Q, Zheng S (2009) Development of polymeric and polymerbased hybrid adsorbents for pollutants removal from waters. Chemical Engineering Journal 151 (1-3):19-29

Polubesova T, Zadaka D, Groisman L, Nir S (2006) Water remediation by micelle-clay system: Case study for tetracycline and sulfonamide antibiotics. Water Research 40 (12):2369-2374

Quesada-Peñate I, Julcour-Lebigue C, Jáuregui-Haza UJ, Wilhelm AM, Delmas H (2009) Comparative adsorption of levodopa from aqueous solution on different activated carbons. Chemical Engineering Journal 152 (1):183-188

Rakić V, Rajić N, Daković A, Auroux A (2012) The adsorption of salicylic acid, acetylsalicylic acid and atenolol from aqueous solutions onto natural zeolites and clays: Clinoptilolite, bentonite and kaolin. Microporous and Mesoporous Materials 
Salman JM, Hameed BH (2010) Removal of insecticide carbofuran from aqueous solutions by banana stalks activated carbon. Journal of Hazardous Materials 176 (1-3):814-819

Sarkar B, Venkateswralu N, Rao RN, Bhattacharjee C, Kale V (2007) Treatment of pesticide contaminated surface water for production of potable water by a coagulationadsorption-nanofiltration approach. Desalination 212 (1-3):129-140

Shukla A, Zhang YH, Dubey P, Margrave JL, Shukla SS (2002) The role of sawdust in the removal of unwanted materials from water. Journal of Hazardous Materials 95 (12):137-152

Snyder SA, Adham S, Redding AM, Cannon FS, DeCarolis J, Oppenheimer J, Wert EC, Yoon Y (2007) Role of membranes and activated carbon in the removal of endocrine disruptors and pharmaceuticals. Desalination 202 (1-3):156-181

Sotelo JL, Ovejero G, Delgado JA, Martínez I (2002) Adsorption of lindane from water onto GAC: Effect of carbon loading on kinetic behavior. Chemical Engineering Journal 87 (1): $111-120$

Spongberg AL, Witter JD (2008) Pharmaceutical compounds in the wastewater process stream in Northwest Ohio. Science of the Total Environment 397 (1-3):148-157

Sun G, Xu X (1997) Sunflower Stalks as Adsorbents for Color Removal from Textile Wastewater. Industrial and Engineering Chemistry Research 36 (3):808-812

Ternes T, Janex-Habibi T, Knaker N, Kreuzinger N, Siegrist H (2004) Assessment of technologies for the removal of pharmaceuticals and personal care products in sewage and drinking water facilities to improve the indirect potable water reuse (POSEIDON project)

Ternes TA (2001) Analytical methods for the determination of pharmaceuticals in aqueous environmental samples. TrAC - Trends in Analytical Chemistry 20 (8):419-434

Togola A, Budzinski H (2008) Multi-residue analysis of pharmaceutical compounds in aqueous samples. Journal of Chromatography A 1177 (1):150-158

Vergili I, Barlas H (2009) Removal of selected pharmaceutical compounds from water by an organic polymer resin. Journal of Scientific and Industrial Research 68 (5):417-425

Verlicchi P, Galletti A, Petrovic M, BarcelÓ D (2010) Hospital effluents as a source of emerging pollutants: An overview of micropollutants and sustainable treatment options. Journal of Hydrology 389 (3-4):416-428

Vieno NM, Tuhkanen T, Kronberg L (2006) Analysis of neutral and basic pharmaceuticals in sewage treatment plants and in recipient rivers using solid phase extraction and liquid chromatography-tandem mass spectrometry detection. Journal of Chromatography A 1134 (1-2):101-111

Wang S, Peng Y (2010) Natural zeolites as effective adsorbents in water and wastewater treatment. Chemical Engineering Journal 156 (1):11-24

Wenzel H, Larsen HF, Clauson-Kaas J, Høibye L, Jacobsen BN (2008) Weighing environmental advantages and disadvantages of advanced wastewater treatment of micro-pollutants using environmental life cycle assessment. Water Science and Technology 57 (1):27-32

Westerhoff P, Yoon Y, Snyder S, Wert E (2005) Fate of endocrine-disruptor, pharmaceutical, and personal care product chemicals during simulated drinking water treatment processes. Environmental Science and Technology 39 (17):6649-6663

Wojnárovits L, Földváry CM, Takács E (2010) Radiation-induced grafting of cellulose for adsorption of hazardous water pollutants: A review. Radiation Physics and Chemistry 79 (8):848-862

Xu J, Wu L, Chang AC (2009) Degradation and adsorption of selected pharmaceuticals and personal care products (PPCPs) in agricultural soils. Chemosphere 77 (10):1299-1305 
Xu RK, Xiao SC, Zhang H, Jiang J, Ji GL (2007) Adsorption of phthalic acid and salicylic acid by two variable charge soils as influenced by sulphate and phosphate. European Journal of Soil Science 58 (1):335-342

Zhang H, Huang CH (2007) Adsorption and oxidation of fluoroquinolone antibacterial agents and structurally related amines with goethite. Chemosphere 66 (8):1502-1512

Zuccato E, Calamari D, Natangelo M, Fanelli R (2000) Presence of therapeutic drugs in the environment. Lancet 355 (9217):1789-1790

Zuhra Memon G, Bhanger MI, Akhtar M (2007) The removal efficiency of chestnut shells for selected pesticides from aqueous solutions. Journal of Colloid and Interface Science 315 (1):33-40

Supplementary Material 1 References of the data contained in the final database (data summarized in Table 1)

1. Adachi A, Takagi S, Okano T. Studies on removal efficiency of rice bran for pesticides. Journal of Health Science 2001; 47 (2): 94-98.

2. Adriano WS, Veredas V, Santana CC, Gonçalves LRB. Adsorption of amoxicillin on chitosan beads: Kinetics, equilibrium and validation of finite bath models. Biochemical Engineering Journal 2005; 27 (2): 132-137.

3. Akhtar M, Iqbal S, Bhanger MI, Moazzam M. Utilization of organic by-products for the removal of organophosphorous pesticide from aqueous media. Journal of Hazardous Materials 2009; 162 (2-3): 703-707.

4. Akhtar M, Hasany SM, Bhanger MI, Iqbal S. Low cost sorbents for the removal of methyl parathion pesticide from aqueous solutions. Chemosphere 2007; 66 (10): 1829-1838.

5. Ayar N, Bilgin B, Atun G. Kinetics and equilibrium studies of the herbicide 2,4dichlorophenoxyacetic acid adsorption on bituminous shale. Chemical Engineering Journal 2008; 138 (1-3): 239-248.

6. Ayranci E, Hoda N. Adsorption kinetics and isotherms of pesticides onto activated carbon-cloth. Chemosphere 2005; 60 (11): 1600-1607.

7. Ayranci E, Hoda N. Adsorption of bentazon and propanil from aqueous solutions at the high area activated carbon-cloth. Chemosphere 2004; 57 (8): 755-762.

8. Bui TX, Choi H. Adsorptive removal of selected pharmaceuticals by mesoporous silica SBA-15. Journal of Hazardous Materials 2009; 168 (2-3): 602-608.

9. Chang PH, Li Z, Yu TL, Munkhbayer S, Kuo TH, Hung YC, Jean JS, Lin KH. Sorptive removal of tetracycline from water by palygorskite. Journal of Hazardous Materials 2009a; 165 (1-3): 148155.

10. Chang PH, Jean JS, Jiang WT, Li Z. Mechanism of tetracycline sorption on rectorite. Colloids and Surfaces A: Physicochemical and Engineering Aspects 2009b; 339 (1-3): 94-99.

11. Chang PH, Li Z, Jiang WT, Jean JS. Adsorption and intercalation of tetracycline by swelling clay minerals. Applied Clay Science 2009c; 46 (1): 27-36.

12. Ding Y, Zhao Y, Tao X, Zheng YZ, Chen JF. Assembled alginate/chitosan micro-shells for removal of organic pollutants. Polymer 2009; 50 (13): 2841-2846.

13. Fernández-Pérez M, Villafranca-Sánchez M, Flores-Céspedes F, Garrido-Herrera FJ, PérezGarcía S. Use of bentonite and activated carbon in controlled release formulations of carbofuran. Journal of Agricultural and Food Chemistry 2005; 53 (17): 6697-6703.

14. Gupta VK, Ali I, Suhas, Saini VK. Adsorption of 2,4-D and carbofuran pesticides using fertilizer and steel industry wastes. Journal of Colloid and Interface Science 2006; 299 (2): 556-563.

15. Hameed BH, Salman JM, Ahmad AL. Adsorption isotherm and kinetic modeling of 2,4-D pesticide on activated carbon derived from date stones. Journal of Hazardous Materials 2009; 163 (1): 121-126.

16. Hu JY, Aizawa T, Ookubo Y, Morita T, Magara Y. Adsorptive characteristics of ionogenic aromatic pesticides in water on powdered activated carbon. Water Research 1998; 32 (9): 25932600.

17. Ignatowicz K. Selection of sorbent for removing pesticides during water treatment. Journal of Hazardous Materials 2009; 169 (1-3): 953-957. 
18. Kyriakopoulos G, Doulia D, Anagnostopoulos E. Adsorption of pesticides on porous polymeric adsorbents. Chemical Engineering Science 2005; 60 (4): 1177-1186.

19. Kouras A, Zouboulis A, Samara C, Kouimtzis T. Removal of pesticides from aqueous solutions by combined physicochemical processes - The behaviour of lindane. Environmental Pollution 1998; 103 (2-3): 193-202.

20. Lemić J, Kovačević D, Tomašević-Čanović M, Kovačević D, Stanić T, Pfend R. Removal of atrazine, lindane and diazinone from water by organo-zeolites. Water Research 2006; 40 (5): 1079-1085.

21. Memon GZ, Bhanger MI, Akhtar M, Talpur FN, Memon JR. Adsorption of methyl parathion pesticide from water using watermelon peels as a low cost adsorbent. Chemical Engineering Journal 2008138 (1-3): 616-621.

22. Memon GZ, Bhanger MI, Akhtar M. The removal efficiency of chestnut shells for selected pesticides from aqueous solutions. Journal of Colloid and Interface Science 2007; 315 (1): 33 40.

23. Mestre AS, Pires J, Nogueira JMF, Parra JB, Carvalho AP, Ania CO. Waste-derived activated carbons for removal of ibuprofen from solution: Role of surface chemistry and pore structure. Bioresource Technology 2009; 100 (5): 1720-1726.

24. Otero M, Grande CA, Rodrigues AE. Adsorption of salicylic acid onto polymeric adsorbents and activated charcoal. Reactive and Functional Polymers 2004; 60 (1-3) 203-213.

25. Polubesova T, Nir S, Zadaka D, Rabinovitz O, Serban C, Groisman L, Rubin B. Water purification from organic pollutants by optimized micelle-clay systems. Environmental Science and Technology 2005; 39 (7): 2343-2348.

26. Polubesova T, Zadaka D, Groisman L, Nir S. Water remediation by micelle-clay system: Case study for tetracycline and sulfonamide antibiotics. Water Research 2006; 40 (12): 2369-2374.

27. Putra EK, Pranowo R, Sunarso J, Indraswati N, Ismadji S. Performance of activated carbon and bentonite for adsorption of amoxicillin from wastewater: Mechanisms, isotherms and kinetics. Water Research 2009; 43 (9): 2419-2430.

28. Quesada-Peñate, I., Julcour-Lebigue, C., Jáuregui-Haza, U.-J., Wilhelm, A.-M., Delmas, H. Comparative adsorption of levodopa from aqueous solution on different activated carbons Chemical Engineering Journal 2009152 (1), pp. 183-188.

29. Salman JM, Hameed BH. Adsorption of 2,4-dichlorophenoxyacetic acid and carbofuran pesticides onto granular activated carbon. Desalination 2010a, 256 (1-3): 129-135.

30. Salman JM, Hameed BH. Removal of insecticide carbofuran from aqueous solutions by banana stalks activated carbon. Journal of Hazardous Materials 2010b; 176 (1-3): 814-819.

31. Salman JM, Hameed BH. Effect of preparation conditions of oil palm fronds activated carbon on adsorption of bentazon from aqueous solutions. Journal of Hazardous Materials 2010c; 175 (13): 133-137.

32. Sarkar B, Venkateswralu N, Rao RN, Bhattacharjee C, Kale V. Treatment of pesticide contaminated surface water for production of potable water by a coagulation-adsorptionnanofiltration approach. Desalination 2007; 212 (1-3): 129-140.

33. Sotelo JL, Ovejero G, Delgado JA, Martínez I. Adsorption of lindane from water onto GAC: Effect of carbon loading on kinetic behaviour. Chemical Engineering Journal 2002a; 87 (1): 111120.

34. Sotelo JL, Ovejero G, Delgado JA, Martínez I. Comparison of adsorption equilibrium and kinetics of four chlorinated organics from water onto GAC. Water Research 2002b; 36 (3): 599 608.

35. Vergili I, Barlas H. Removal of selected pharmaceutical compounds from water by an organic polymer resin. Journal of Scientific and Industrial Research 2009; 68 (5): 417-425.

36. Xu RK, Xiao SC, Zhang H, Jiang J, Ji GL. Adsorption of phthalic acid and salicylic acid by two variable charge soils as influenced by sulphate and phosphate. European Journal of Soil Science 2007; 58 (1): 335-342.

37. Yang Y, Chun Y, Shang G, Huang M. pH-dependence of pesticide adsorption by wheat-residuederived black carbon. Langmuir 2004; 20 (16): 6736-6741.

38. Zhang $\mathrm{H}$, Huang $\mathrm{CH}$. Adsorption and oxidation of fluoroquinolone antibacterial agents and structurally related amines with goethite. Chemosphere 2007; 66 (8): 1502-1512. 
Supplementary Material 2 Xenobiotics studied via adsorption batch assays in literature

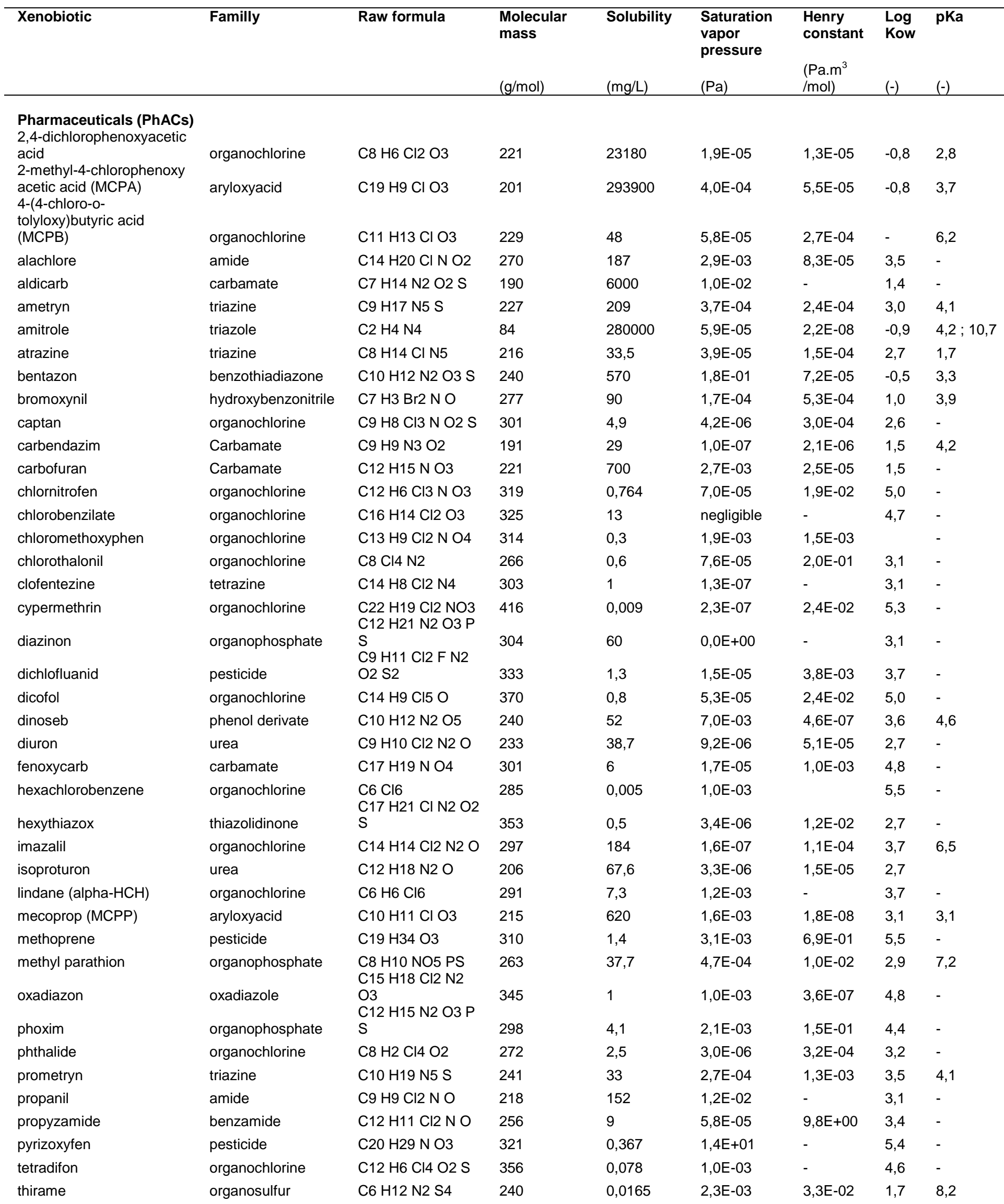




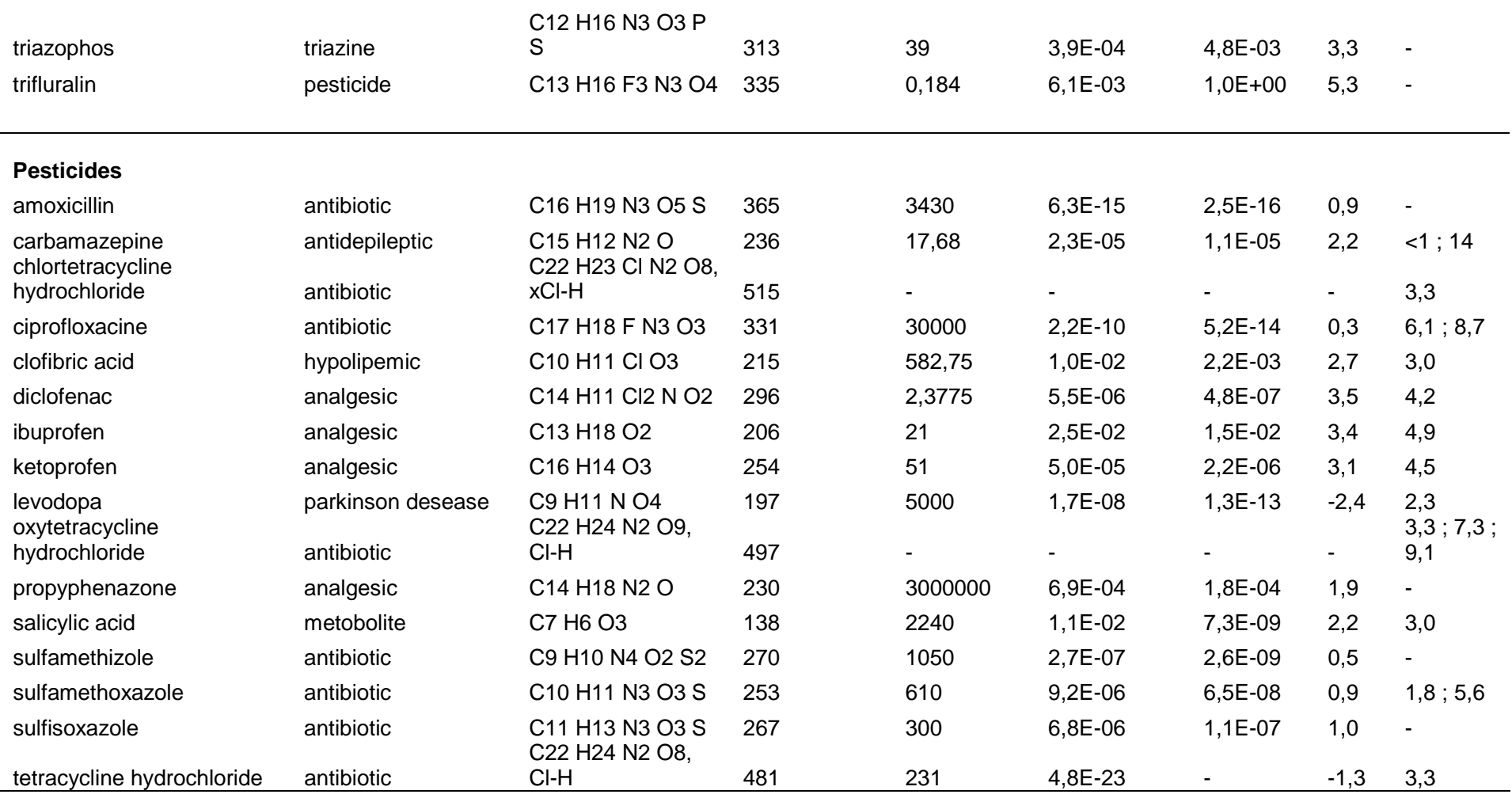


Supplementary Material 3 Experimental conditions of adsorption batch assays found in literature

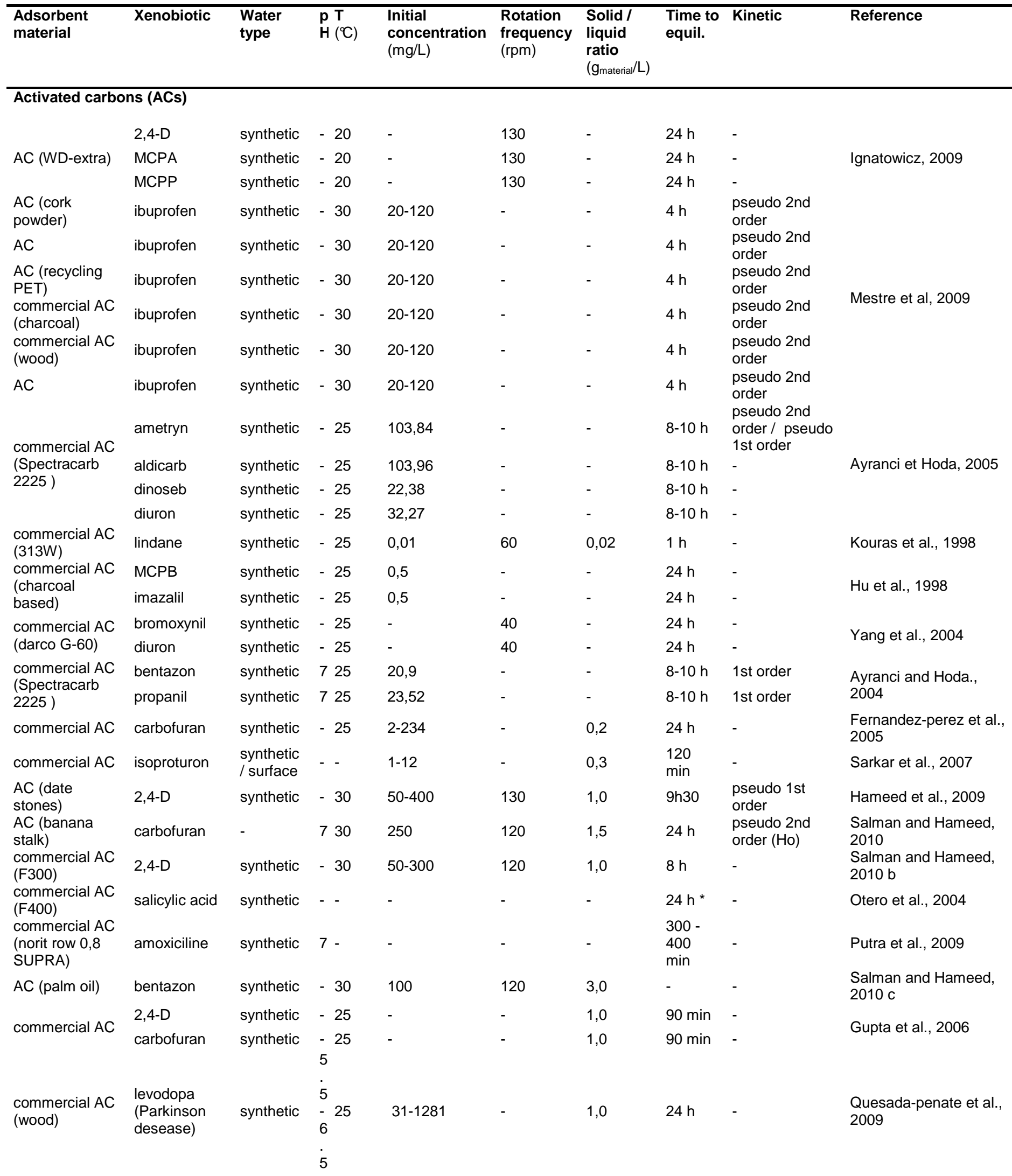




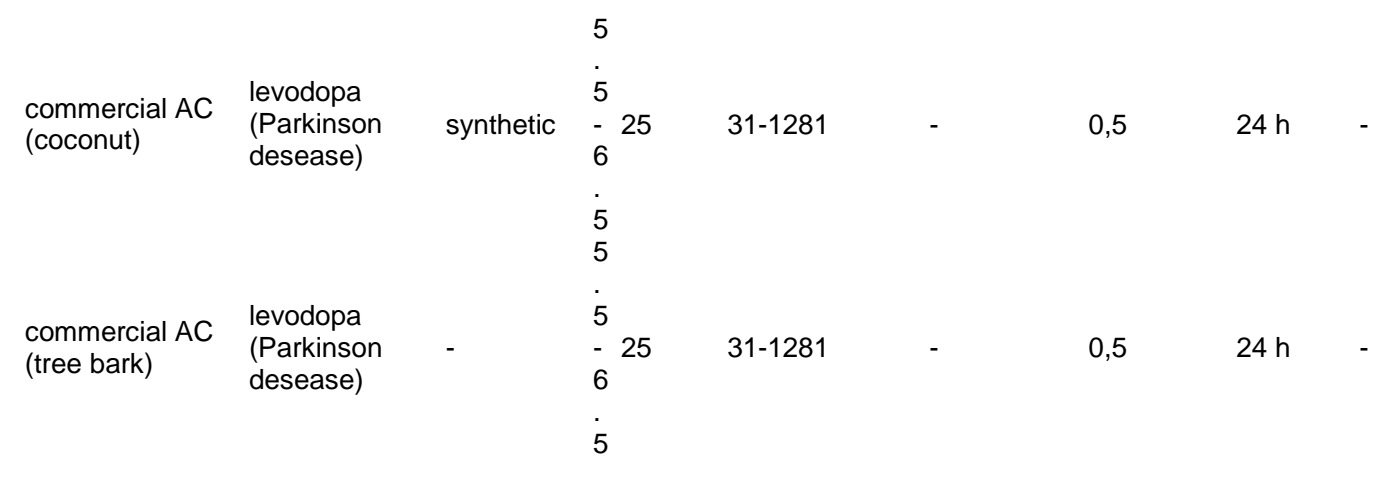

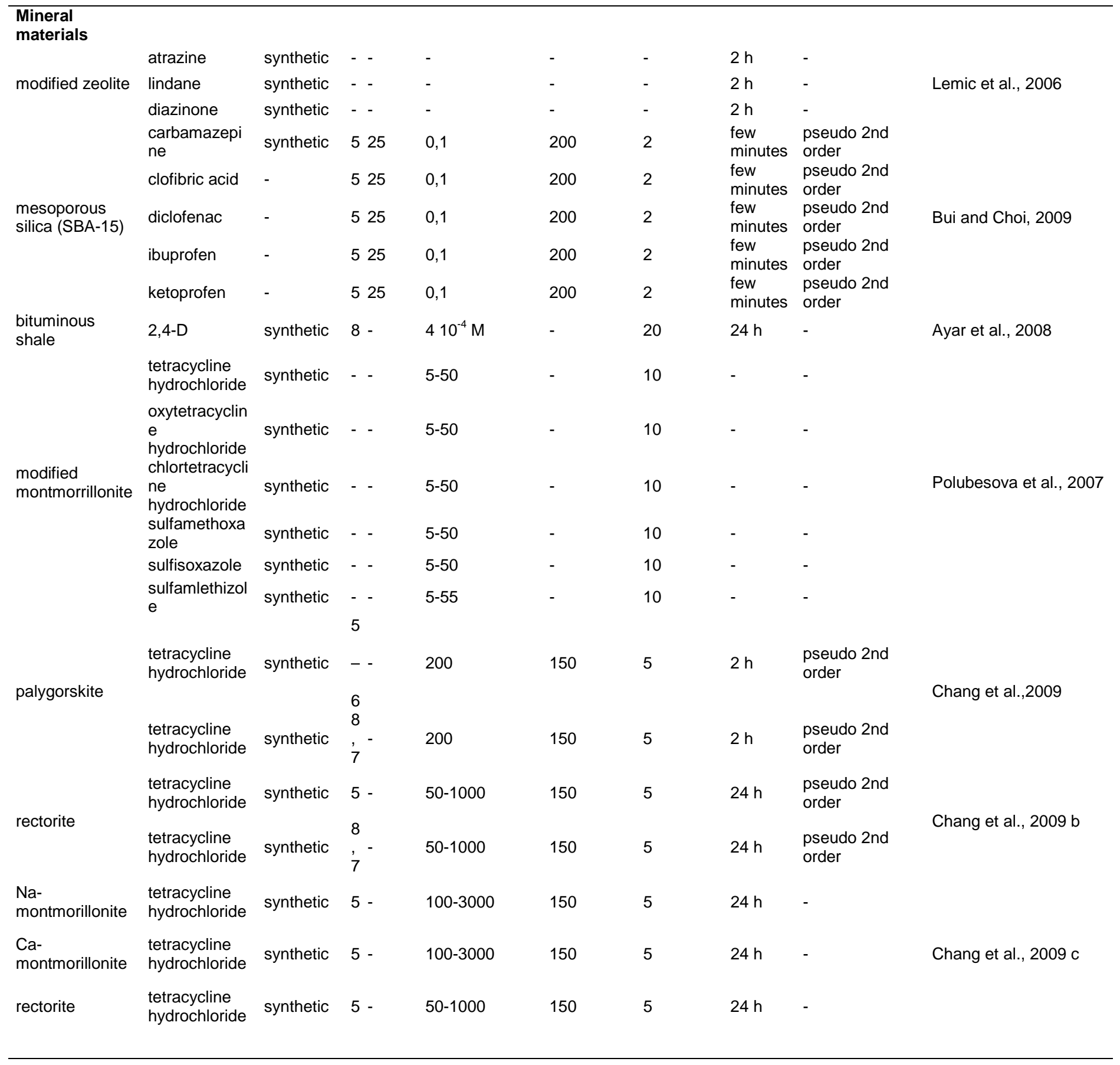




\section{Other}

materials

\begin{tabular}{|c|c|c|c|c|c|}
\hline & captan & - & - & 50 & - \\
\hline & $\begin{array}{l}\text { chloromethox } \\
\text { yphen }\end{array}$ & - & -- & 50 & - \\
\hline & $\begin{array}{l}\text { chloronitroph } \\
\text { en }\end{array}$ & - & - & 50 & - \\
\hline & cypermethrin & - & - & 2 & - \\
\hline & dichlofluanid & - & - & 50 & - \\
\hline & fenoxycarb & - & -- & 50 & - \\
\hline & fthalide & - & -- & 50 & - \\
\hline & lindane & - & -- & 50 & - \\
\hline & $\begin{array}{l}\text { hexachlorobe } \\
\text { nzene }\end{array}$ & - & - & 50 & - \\
\hline & hexythiazox & - & -- & 50 & - \\
\hline rice bran & kelthane & - & -- & 50 & - \\
\hline & methoprene & - & - & 50 & - \\
\hline & carbe-azim & - & -- & 50 & - \\
\hline & oxadiazon & - & -- & 50 & - \\
\hline & phoxim & - & -- & 50 & - \\
\hline & propyzamide & - & - & 50 & - \\
\hline & pyrazoxyfen & - & -- & 50 & - \\
\hline & tetradifon & - & -- & 50 & - \\
\hline & $\begin{array}{l}\text { cholorobenzil } \\
\text { ate }\end{array}$ & - & - & 50 & - \\
\hline & triuram & - & -- & 50 & - \\
\hline & clofentezine & - & -- & 50 & - \\
\hline & chorothalonil & - & -- & 50 & - \\
\hline $\begin{array}{l}\text { watermelon } \\
\text { peel }\end{array}$ & $\begin{array}{l}\text { methyl } \\
\text { parathion }\end{array}$ & - & $6-$ & 1000 & 100 \\
\hline & carbofuran & - & 630 & 840 & 100 \\
\hline chestnut shell & $\begin{array}{l}\text { methyl } \\
\text { parathion }\end{array}$ & - & $6-$ & 1200 & - \\
\hline rice husk & hostathion & - & 630 & 10 & 100 \\
\hline rice bran & hostathion & - & 630 & 10 & 100 \\
\hline rice bran & $\begin{array}{l}\text { methyl } \\
\text { parathion }\end{array}$ & - & 630 & 100 & 100 \\
\hline rice husk & $\begin{array}{l}\text { methyl } \\
\text { parathion }\end{array}$ & - & 630 & 100 & 100 \\
\hline fly ash & $\begin{array}{l}\text { methyl } \\
\text { parathion }\end{array}$ & - & 630 & 100 & 100 \\
\hline $\begin{array}{l}\text { moringa olifeira } \\
\text { husk }\end{array}$ & $\begin{array}{l}\text { methyl } \\
\text { parathion }\end{array}$ & - & 630 & 100 & 100 \\
\hline polymeric resin & $\begin{array}{l}\text { carbamazepi } \\
\text { ne }\end{array}$ & synthetic & -25 & 0,02 & 150 \\
\hline (lewatit VP OC & $\begin{array}{l}\text { propyphenaz } \\
\text { one }\end{array}$ & synthetic & -25 & 0,02 & 150 \\
\hline & $\begin{array}{l}\text { sulfamethoxa } \\
\text { zole }\end{array}$ & synthetic & -25 & 0,02 & 150 \\
\hline chisosan & $2,4-D$ & synthetic & $7-$ & $0.3-5.610^{-4} \mathrm{M}$ & - \\
\hline alginates & salicylic acid & synthetic & $7-$ & $0.3-5.610^{-4} \mathrm{M}$ & - \\
\hline $\begin{array}{l}\text { sephabeads } \\
\text { SP207 }\end{array}$ & salicylic acid & synthetic & -- & - & - \\
\hline bentonite & amoxiciline & synthetic & $7-$ & - & - \\
\hline $\begin{array}{l}\text { goethite (syn- } \\
\text { FeOOH) }\end{array}$ & ciprofloxacine & synthetic & -- & - & - \\
\hline $\begin{array}{l}\text { goethite (ald- } \\
\text { Fe-OOH) }\end{array}$ & ciprofloxacine & synthetic & -- & - & - \\
\hline chitosan & amoxiciline & synthetic & -- & - & - \\
\hline goethite & salicylic acid & synthetic & - - & - & - \\
\hline kaolinite & salicylic acid & synthetic & - - & - & - \\
\hline
\end{tabular}

10

10

10

10

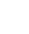

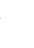

8

(

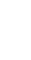

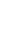

4

4

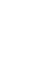

5

$\begin{array}{lll}60 \mathrm{~min} & 1 \text { st order } & \text { Memon et al., } 2008 \\ 30 \mathrm{~min} & 1 \text { st order } & \\ 30 \mathrm{~min} & - & \text { Memon et al., } 2007\end{array}$




\begin{tabular}{|c|c|c|c|c|c|c|c|c|c|}
\hline rhodic ferrasol & salicylic acid & synthetic & - & - & - & - & $22 \mathrm{~h}$ * & - & \multirow{5}{*}{$\begin{array}{l}\text { Kiriakopoulos et al., } \\
2005\end{array}$} \\
\hline haplic acrisol & salicylic acid & synthetic & - & - & - & - & $22 h^{*}$ & - & \\
\hline \multirow{3}{*}{$\begin{array}{l}\text { XAD-7 } \\
\text { (polymeric) } \\
\text { XAD-4 } \\
\text { (polyeric) }\end{array}$} & herbicide & synthetic & - $15-30$ & $200-1000$ & & $50-100$ & $4 \mathrm{~h}$ & - & \\
\hline & herbicide & synthetic & $-15-30$ & $200-1000$ & & $50-100$ & $4 \mathrm{~h}$ & - & \\
\hline & & & 6 & & & & & & \\
\hline \multirow[t]{2}{*}{$\begin{array}{l}\text { carbonaceous } \\
\text { material }\end{array}$} & $\begin{array}{l}2,4-\mathrm{D} / \\
\text { carbofuran }\end{array}$ & synthetic & $\begin{array}{l}5 \\
- \\
7\end{array}$ & - & - & 1 & $90 \mathrm{~min}$ & 2nd order & \multirow{7}{*}{ Gupta et al., 2006} \\
\hline & & & $\begin{array}{l}5 \\
6\end{array}$ & & & & & & \\
\hline \multirow[t]{2}{*}{$\begin{array}{l}\text { blast furnace } \\
\text { (BF) sludge }\end{array}$} & $\begin{array}{l}\text { 2,4-D / } \\
\text { carbofuran }\end{array}$ & synthetic & $\begin{array}{l}5 \\
- \\
7\end{array}$ & - & - & 1 & $90 \mathrm{~min}$ & 2nd order & \\
\hline & & & $\begin{array}{l}6 \\
6\end{array}$ & & & & & & \\
\hline \multirow[t]{2}{*}{$\begin{array}{l}\text { blast furnace } \\
\text { dust }\end{array}$} & $\begin{array}{l}\text { 2,4-D / } \\
\text { carbofuran }\end{array}$ & synthetic & $\begin{array}{l}5 \\
-- \\
7\end{array}$ & - & - & 1 & $90 \min$ & 2nd order & \\
\hline & & & $\begin{array}{l}7 \\
6\end{array}$ & & & & & & \\
\hline \multirow[t]{2}{*}{$\begin{array}{l}\text { blast furnace } \\
\text { slag }\end{array}$} & $\begin{array}{l}2,4-\mathrm{D} / \\
\text { carbofuran }\end{array}$ & synthetic & $\begin{array}{l}5 \\
-- \\
7\end{array}$ & - & - & 1 & $90 \mathrm{~min}$ & 2nd order & \\
\hline & & & 8 & & & & & & \\
\hline
\end{tabular}

* reaction time but not specified to be equilibrium time 
Supplementary Material 4 Adsorbent materials studied via adsorption batch assays in literature

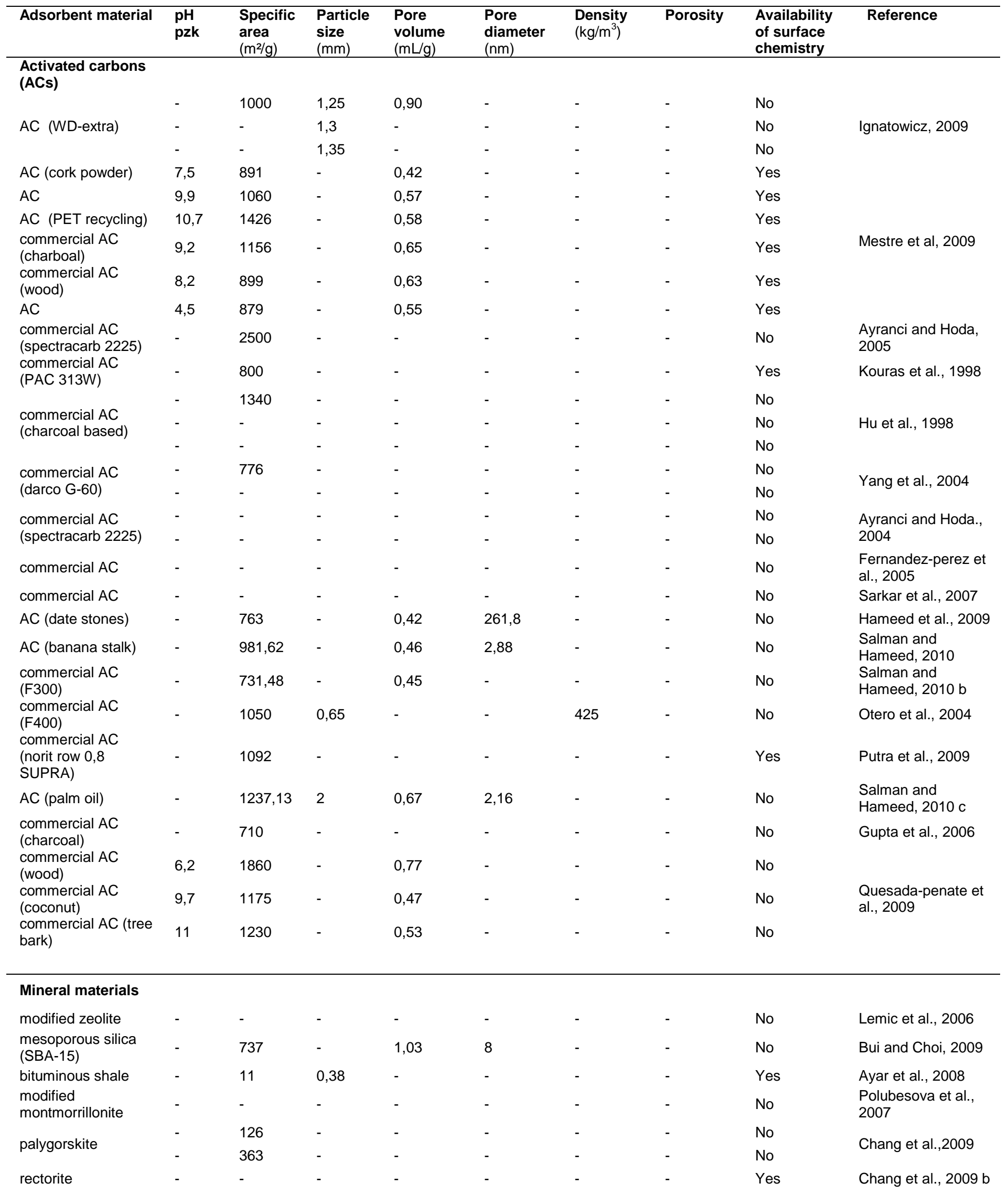




\begin{tabular}{|c|c|c|c|c|c|c|c|c|c|}
\hline Na-montmorillonite & - & 725 & - & - & - & - & - & Yes & \\
\hline Ca-montmorillonite & - & 717 & - & - & - & - & - & Yes & Chang et al., $2009 \mathrm{c}$ \\
\hline rectorite & - & 363 & - & - & - & - & - & Yes & \\
\hline \multicolumn{10}{|l|}{ Other materials } \\
\hline rice bran & - & 0,14 & - & - & - & - & - & No & Adachi et al., 2001 \\
\hline watermelon peel & - & 23,4 & - & - & - & - & - & No & Memon et al., 2008 \\
\hline chestnut shell & - & 42 & - & - & - & - & - & Yes & Memon et al., 2007 \\
\hline rice husk & - & 11 & - & 0,70 & 41 & - & - & Yes & \multirow{2}{*}{ Akhtar et al., 2009} \\
\hline rice bran & - & 19 & - & 0,72 & 78 & - & - & Yes & \\
\hline rice bran & - & 28 & - & 0,66 & 88 & - & - & Yes & \multirow{3}{*}{ Akhtar et al., 2007} \\
\hline rice husk & - & 17 & - & 0,69 & 51 & - & - & Yes & \\
\hline fly ash & - & 25 & - & 0,71 & 77 & - & - & Yes & \\
\hline moringa olifeira husk & - & 27 & - & 0,72 & 86 & - & - & Yes & \\
\hline $\begin{array}{l}\text { polymeric resin } \\
\text { (lewatit VP OC } \\
\text { 1163) }\end{array}$ & - & 1300 & 0,5 & 0,70 & 5 & - & - & Yes & $\begin{array}{l}\text { Vergili and Barlas, } \\
2009\end{array}$ \\
\hline chisosan alginates & - & - & - & - & - & - & - & No & Ding et al., 2009 \\
\hline sephabeads SP207 & - & 627 & 0,4 & - & - & 1180 & - & No & \multirow{2}{*}{ Otero et al., 2004} \\
\hline sephabeads SP206 & - & 557 & 0,4 & - & - & 1190 & - & No & \\
\hline bentonite & - & 92 & - & - & - & - & - & Yes & Putra et al., 2009 \\
\hline $\begin{array}{l}\text { goethite (syn- } \\
\text { FeOOH) }\end{array}$ & - & 159 & - & - & - & - & - & No & \multirow{2}{*}{$\begin{array}{l}\text { Zhang and Huang } \\
2007\end{array}$} \\
\hline $\begin{array}{l}\text { goethite (ald-Fe- } \\
\mathrm{OOH} \text { ) }\end{array}$ & - & 82 & - & - & - & - & - & No & \\
\hline chitosan & - & - & 2,12 & - & - & 1,005 & 0,82 & No & Adriano et al., 2005 \\
\hline goethite & - & - & - & - & - & - & - & Yes & \multirow{4}{*}{ Xu et al., 2007} \\
\hline kaolinite & - & - & - & - & - & - & - & Yes & \\
\hline rhodic ferrasol & - & - & - & - & - & - & - & Yes & \\
\hline haplic acrisol & - & - & - & - & - & - & - & Yes & \\
\hline XAD-7 (polymeric) & - & 450 & 0,42 & - & 30 & - & 0,50 & No & \multirow{2}{*}{$\begin{array}{l}\text { Kiriakopoulos et al., } \\
2005\end{array}$} \\
\hline XAD-4 (polyeric) & - & 750 & 0,42 & - & 5 & - & 0,40 & No & \\
\hline $\begin{array}{l}\text { carbonaceous } \\
\text { material }\end{array}$ & - & 380 & - & - & - & - & - & No & \multirow{4}{*}{ Gupta et al., 2006} \\
\hline $\begin{array}{l}\text { blast furnace (BF) } \\
\text { sludge }\end{array}$ & - & 28 & - & - & - & - & - & No & \\
\hline blast furnace dust & - & 13 & - & - & - & - & - & No & \\
\hline blast furnace slag & - & 4 & - & - & - & - & - & No & \\
\hline
\end{tabular}

